\title{
An untargeted multi-technique metabolomics approach to studying intracellular metabolites of HepG2 cells exposed to 2,3,7,8-tetrachlorodibenzo- p-dioxin
}

\author{
Ainhoa Ruiz-Aracama ${ }^{1,3^{*}}$, Ad Peijnenburg, ${ }^{1,3}$, Jos Kleinjans ${ }^{2,3}$, Danyel Jennen ${ }^{2,3}$, Joost van Delft ${ }^{2,3}$,
} Caroline Hellfrisch ${ }^{1}$ and Arjen Lommen ${ }^{1,3}$

\begin{abstract}
Background: In vitro cell systems together with omics methods represent promising alternatives to conventional animal models for toxicity testing. Transcriptomic and proteomic approaches have been widely applied in vitro but relatively few studies have used metabolomics. Therefore, the goal of the present study was to develop an untargeted methodology for performing reproducible metabolomics on in vitro systems. The human liver cell line HepG2, and the well-known hepatotoxic and non-genotoxic carcinogen 2,3,7,8-tetrachlorodibenzo-p-dioxin (TCDD), were used as the in vitro model system and model toxicant, respectively.

Results: The study focused on the analysis of intracellular metabolites using NMR, LC-MS and GC-MS, with emphasis on the reproducibility and repeatability of the data. State of the art pre-processing and alignment tools and multivariate statistics were used to detect significantly altered levels of metabolites after exposing HepG2 cells to TCDD. Several metabolites identified using databases, literature and LC-nanomate-Orbitrap analysis were affected by the treatment. The observed changes in metabolite levels are discussed in relation to the reported effects of TCDD.

Conclusions: Untargeted profiling of the polar and apolar metabolites of in vitro cultured HepG2 cells is a valid approach to studying the effects of TCDD on the cell metabolome. The approach described in this research demonstrates that highly reproducible experiments and correct normalization of the datasets are essential for obtaining reliable results. The effects of TCDD on HepG2 cells reported herein are in agreement with previous studies and serve to validate the procedures used in the present work.
\end{abstract}

\section{Background}

Metabolomics has been defined as the quantitative measurement of the multi-parametric metabolic response of living systems to patho-physiological stimuli or genetic modification [1]. It encompasses the qualitative and quantitative measurement of metabolites interacting in a biological system; targeted and untargeted strategies for analysis of metabolites can be used. Targeted studies focus on the analysis of a predefined list of metabolites, whereas the initial objective of untargeted metabolomics

\footnotetext{
* Correspondence: Ainhoa.ruiz@wur.nl

'RIKILT-Institute of Food Safety, Wageningen University and Research Centre, P.O. Box 230, 6700 AE, Wageningen, The Netherlands

Full list of author information is available at the end of the article
}

is to analyze as many non-predefined metabolites as possible at the raw signal level. With the latter approach, identification is only carried out on relevant signals $[2,3]$.

Recently, there has been an exponential growth in the number of published papers concerning metabolomics of a wide variety of systems [4-7]. Metabolomic approaches have been used for toxicological studies [8]. However, in most cases, biofluids or tissues from in vivo experiments have been analyzed $[8,9]$. Few toxicological studies have been published that concern the profiling of intracellular metabolites using in vitro cell culture systems $[10,11]$

\section{C) Biomed Central}

(c) 2011 Ruiz-Aracama et al; licensee BioMed Central Ltd. This is an Open Access article distributed under the terms of the Creative Commons Attribution License (http://creativecommons.org/licenses/by/2.0), which permits unrestricted use, distribution, and reproduction in any medium, provided the original work is properly cited. 
Owing to ethical concerns (animal welfare) and cost efficiency, there is a need to develop alternatives to conventional toxicity testing incorporating animals [12]. Among these alternatives, in vitro systems are considered particularly promising $[13,14]$. Much research has focused on the analysis of the effects of toxic compounds using in vitro systems and omics techniques [15-18]. However, transcriptomics and proteomics have predominantly been used to elucidate the toxic mechanisms of the studied compounds.

The goals of the present work were two-fold. First, to develop an untargeted in vitro cell system methodology with reproducible metabolomics; second, to evaluate toxicant-induced cell responses on metabolic levels with regards to published data concerning the toxicant, thereby substantiating the methodology. TCDD $(2,3,7,8-$ tetrabenzodi-p-dioxin) was chosen as the model toxic compound as it has been widely studied in vivo and in vitro $[15,19,20]$, particularly in terms of its hepatotoxic, carcinogenic and immunotoxic effects. Toxic effects of dioxins mediated by the aryl hydrocarbon receptor (AhR) include the wasting syndrome [21], the induction of oxidative damage [22,23], hepatic injury and carcinogenesis $[24,25]$. TCDD has also been reported to have an anti-proliferative effect [26].

TCDD is an agonist of AhR, a cytosolic ligand-activated transcription factor. Upon activation, AhR dimerizes with ARNT to form a heterodimer that binds to DNA sequences called xenobiotic response elements (XREs). Through such binding, AhR up-regulates the expression of several downstream genes including those encoding xenobiotic metabolizing enzymes such as Phase I (e.g. cytochrome P450 monooxygenases) and Phase II (e.g. glutathione S-transferases, sulfotransferases) biotransformation enzymes [27].

In this study, the human hepatoma cell line HepG2 was chosen for experiments concerning in vitro exposure to TCDD as this compound is a well known liver toxicant. HepG2 cells have preserved the activities of several phase I and phase II enzymes [28]. Consequently, HepG2 cells have been widely used as a model for various omics studies concerning carcinogenicity and hepatotoxicity [28-30]. Furthermore, this cell line has been exploited for studying the effects of TCDD on gene expression using transcriptomics [15-17,26].

For the untargeted metabolomics approach used in this study, multiple complementary analytical techniques were applied to polar and apolar cell lysate fractions, i.e. NMR and GCMS to the apolar fraction, and NMR and LCMS to the polar fraction. Data analysis was performed using state-of-the-art software [31-33] for preprocessing and alignment of data sets in combination with multivariate statistical analysis and advanced identification technology.
Particular emphasis was placed on the repeatability of experiments, reproducibility of metabolic changes, normalization and validation of the results by literature comparison.

\section{Results}

The advantages and limitations of omics techniques applied to in vitro systems must be elucidated before in vitro omics-based alternatives to conventional toxicity studies are considered valid. The goal of the present study was to develop a reproducible untargeted metabolomics methodology for in vitro studies using the HepG2 human hepatocarcinoma cell line exposed to TCDD for $48 \mathrm{~h}$.

Cell extracts containing intracellular metabolites were separated into polar and apolar fractions and subjected to $1 \mathrm{D}{ }^{1} \mathrm{H}-\mathrm{NMR}$ and LC-MS or $1 \mathrm{D}{ }^{1} \mathrm{H}-\mathrm{NMR}$ and GC-MS, respectively. The majority of NMR and MS data obtained were complementary in terms of their information content. Raw data were pre-processed and aligned using specific software enabling statistical analysis. Subsequently, metabolites with significantly altered levels were identified using databases, literature and LC-nanomate-Orbitrap analysis. In this study, a particular focus concerned the repeatability of experiments with HepG2 cells obtained from different passages, and reproducibility of biological replicates from the same passage, and normalization of experimental data prior to comparison. Results were compared with data from previous studies concerning the effects of TCDD in non-metabolomics studies.

The first major problem addressed was the normalization of chemical profiles. In this study, typical changes in metabolite concentrations were between 20 and $100 \%$. Compounds such as TCDD can influence overall cell metabolism and cause a decrease in the rate of cell proliferation. Therefore, the net effect of exposure can be an overall decrease of metabolites because there is less cell material. If this is not taken into account it will dominate the metabolomics results and metabolic effects may go undetected. Furthermore, in order to identify statistically significant changes in metabolite concentrations in the order of 20 to $100 \%$, it was essential to have multiple replicates.

Preliminary studies in our laboratory have shown that the age of cell cultures (expressed as passage number) could influence the magnitude of the effect of the exposure on the cell metabolome. To address this issue, HepG2 cells obtained from different passage numbers were exposed to medium containing $10 \mathrm{nM}$ TCDD or the vehicle, DMSO, for a period of $48 \mathrm{~h}$.

\section{The apolar fraction}

NMR analyses of the apolar fraction were performed using the same deuterated chloroform. Therefore, the 
residual proton signal of chloroform was used as an initial absolute internal standard. This allowed the amount of lipids in solution to be estimated by calculating the ratio between the sum of the intensities of all spectral signals $($ TS (total signals) $=$ signals $1-22$ in Figure 1) and the intensity of the residual $\mathrm{CHCl}_{3}$ signal (not shown). These ratios are presented in the bar graph of Figure 2, panel A. The TS/ $\mathrm{CHCl}_{3}$ ratio was significantly higher in DMSO samples than in TCDD samples, indicating that the latter extracts contained less total lipid.

TS predominantly represented membrane constituents and triglycerides. Membranes are thought to be relatively constant in terms of composition. Since membrane constituents such as phospholipids (PL) are easily detected in NMR-spectra, it was assumed that generic phospholipid signals (such as signals 18 and 20 in Figure 1 ; backbone signal for non-lyso-PL and lyso-PL) could be used as an internal measure for the amount of membrane and thus for the number of cells. No specific signals representing lyso-PL could be detected in the NMR spectrum, indicating that this species makes a negligible contribution to the total phospholipids. This was corroborated by other known membrane constituents including free cholesterol and polyunsaturated fatty acids, which had constant ratios to the phospholipids (vide infra). Normalization using a PL signal as an internal standard gave excellent results when the spectra were compared manually and when the PCA results were considered. Since a PL signal is an internal standard, it will reflect directly potential differences in biological replicate flasks and may reflect possible small differences in sample handling; therefore this normalization method is better than using an external standard such as a cell counting average obtained from additional cell culture flasks. A better normalization allows for the detection of smaller differences in concentrations of metabolites.

The ratio between the intensity of the PL signal (signal 20 in Figure 1) and $\mathrm{CHCl}_{3}\left(\mathrm{PL} / \mathrm{CHCl}_{3}\right)$, presented in Figure 2, panel $\mathrm{B}$, was used to normalize the data before multivariate analysis (MVA) was carried out. DMSO control extracts contained more phospholipids, and therefore more cells, than TCDD extracts (Figure 2). The difference in the number of cells between TCDDexposed and control samples was significant for passage numbers 30,7 and 11 . For passage numbers $11 \mathrm{~b}$ and 17, the differences in cell numbers did not reach significance.

When scaling on PL signals (Figure 1), the signal corresponding to the bis-allylic protons of long chain polyunsaturated acyl groups (PUFA; signal 14 in Figure 1) at $2.84 \mathrm{ppm}$ was not changed, indicating unaltered levels of long chain PUFAs upon TCDD treatment. Furthermore, the signal relating to free cholesterol (signal 6 in Figure 1) was not altered. Long chain PUFAs and free cholesterol are important components of membranes and it was expected that these components would correlate with membrane-related phospholipid signals.

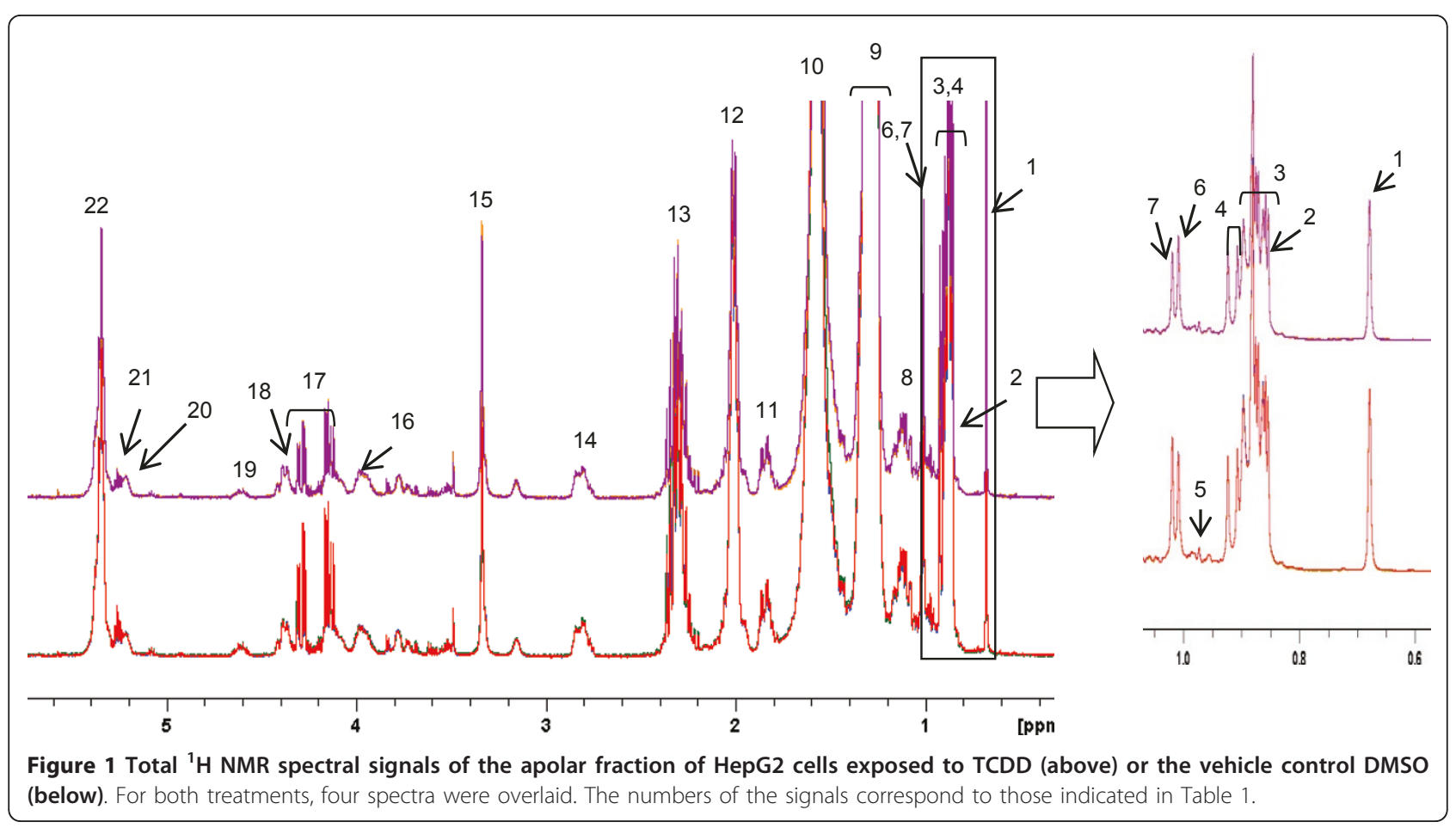



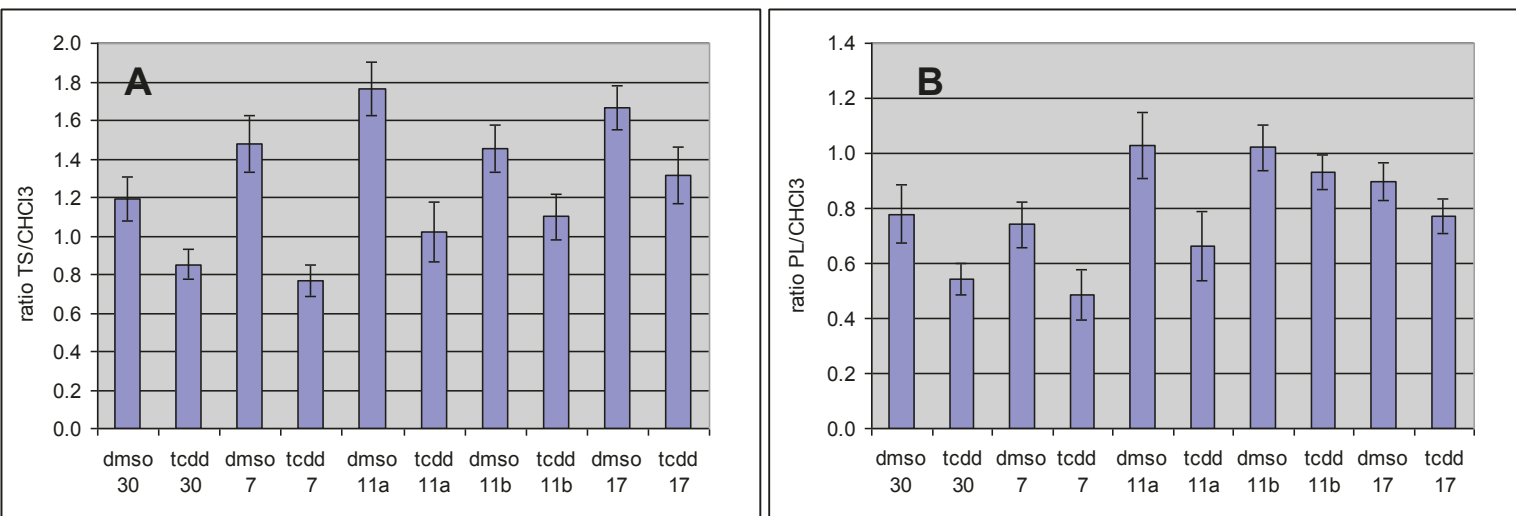

Figure 2 Ratios between the intensity of some NMR spectral signals. A: Ratio between the intensity of the total NMR spectral signals (TS) and the intensity of the residual $\mathrm{CHCl}_{3}$ signal. B: Ratio between the intensity of the phospholipid signal in the NMR spectra (PL) and the intensity of the residual $\mathrm{CHCl}_{3}$ signal.

Representative ${ }^{1} \mathrm{H}$ NMR spectra replicates of apolar extracts of HepG2 cells scaled on the PL signal are overlaid in Figure 1, and the assignment of the signals is given in Table 1. Figure 1 demonstrates an excellent overlapping of biological replicates of controls and of

Table 1 Assignment of the ${ }^{1} \mathrm{H}$ NMR spectral signals of the apolar fraction

\begin{tabular}{|c|c|c|}
\hline $\begin{array}{c}\text { Peak } \\
\text { number }\end{array}$ & $\begin{array}{l}\text { Chemical shift } \\
\text { (ppm) }\end{array}$ & Assignment $^{a}$ \\
\hline 1 & 0.68 & Total cholesterol $\mathrm{C}^{18} \mathrm{H}_{3}$ \\
\hline 2 & $0.85 / 0.86$ & Total cholesterol $\mathrm{C}^{26} \mathbf{H}_{3} / \mathrm{C}^{27} \mathbf{H}_{3}$ \\
\hline 3 & $0.86-0.91$ & Acyl groups $\mathrm{CH}_{\mathbf{3}}$ (all except n-3) \\
\hline 4 & 0.92 & Total cholesterol $\mathrm{C}^{21} \mathbf{H}_{\mathbf{3}}$ \\
\hline 5 & 0.98 & n-3 acyl groups $\mathrm{CH}_{\mathbf{3}}$ \\
\hline 6 & 1.01 & Free cholesterol $\mathrm{C}^{19} \mathbf{H}_{\mathbf{3}}$ \\
\hline 7 & 1.02 & Esterified cholesterol $\mathrm{C}^{19} \mathbf{H}_{3}$ \\
\hline 8 & $1.06-1.19$ & Multiple cholesterol protons \\
\hline 9 & $1.20-1.38$ & Acyl groups $-\left(\mathrm{CH}_{2}\right) \mathrm{n}-$ \\
\hline 10 & $1.50-1.65$ & $\begin{array}{l}\text { Acyl groups -OCO-CH}-\mathrm{CH}_{2}-\mathrm{CH}_{2}-\text { and } \\
\qquad \mathbf{H}_{2} \mathrm{O}\end{array}$ \\
\hline 11 & $1.79-1.88$ & Multiple cholesterol protons \\
\hline 12 & $1.97-2.10$ & Acyl groups $-\mathrm{CH}_{2}-\mathrm{CH}=\mathrm{CH}-$ \\
\hline 13 & $2.24-2.38$ & Acyl groups -OCO- $\mathrm{CH}_{2}^{-}$ \\
\hline 14 & $2.72-2.88$ & Acyl groups $=\mathrm{HC}-\mathrm{CH}_{2}-\mathrm{CH}=$ \\
\hline 15 & $3.28-3.38$ & Choline $\mathrm{N}\left(\mathrm{CH}_{3}\right)_{3}$ \\
\hline 16 & $3.90-4.02$ & Glycerophospholipids $\mathrm{N}-\mathrm{CH}_{2}$ \\
\hline 17 & $4.10-4.32$ & Glycerol backbone - $\mathrm{CH}_{2} \mathrm{OCOR}$ \\
\hline 18 & $4.33-4.43$ & Phosphatidylcholine PO-CH \\
\hline 19 & $4.50-4.66$ & Esterified cholesterol $\mathrm{C}^{3} \mathbf{H}$ \\
\hline 20 & $5.17-5.24$ & $\begin{array}{c}\text { Glycerophospholipid backbone } \\
\text { >CHOCOR }\end{array}$ \\
\hline 21 & $5.24-5.28$ & Glycerol backbone >CHOCOR \\
\hline 22 & $5.29-5.43$ & Acyl groups $-\mathrm{CH}=\mathrm{CH}-$ \\
\hline
\end{tabular}

Numbers correspond to those in Figure 1.

aprotons assignment based on [81] treated cell extracts. The main differences observed between the treated and non-treated cell extracts were related to triglyceride signals.

NMR data were pre-processed and aligned using a program developed in-house [32,33]. The aligned fingerprint data were normalized using the $\mathrm{PL} / \mathrm{CHCl}_{3}$ ratio and exported in the form of spreadsheets for further multivariate analysis. Figure 3A presents a PCA plot (after pre-selection using ${ }^{2} \log$ transformation and an ANOVA where $\mathrm{p}<0.01$ ) and demonstrates that the biological replicates of each sample were clustered (with or without ANOVA pre-selection; data not shown). It is remarkable that the passage number had an important effect, reflecting the difference in the magnitude of the effect of TCDD.

An alternative method of mining these normalized data sets is to perform a PCA after consecutively doing a ${ }^{2} \log$ transformation, a regrouping towards treatment (TCDD) and control (DMSO), and an ANOVA ( $\mathrm{p}<$ 0.01) (Figure 3B). From the underlying peak loadings (additionally surviving a Bonferroni correction) responsible for the separation of samples in this PCA, it is possible to create a list of resonance positions that contribute significantly to the observed separation between the apolar fractions of cells exposed to TCDD and controls. The expected decrease in triglyceride content, as observed in Figure 1 (signal 17), was the major difference between the treated and non-treated samples (average ratio TCDD: DMSO $=0.5$ ). This effect, clearly observed during visual inspection of the NMR spectra, differed significantly in the five experiments conducted. Furthermore, the concentration of cholesterol ester was decreased (average ratio TCDD: DMSO $=0.7$ ) after TCDD treatment (see Figure 1 signal 7). The decreases in triglyceride and cholesterol ester content were accompanied by a decrease in the intensity of the signals 

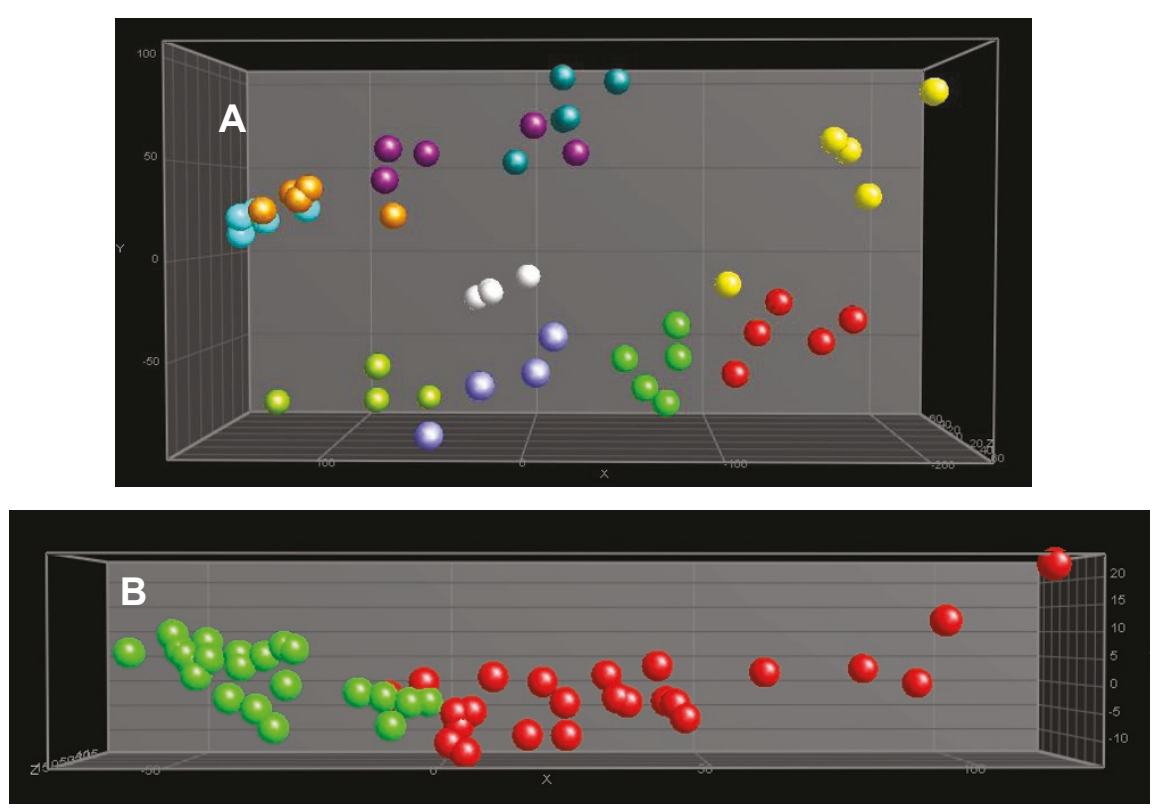

Figure 3 PCA plots (after ANOVA $p<0.01$ ) of the apolar fraction of HepG2 analyzed by ${ }^{1} \mathrm{H}$ NMR and pre-processed and aligned using a program developed in-house. A: Spheres with the same colour are technical replicates of the same sample per passage number. DMSO30: green; TCDD30: red; DMSO7: lila; TCDD7: yellow; DMSO11b: light blue; TCDD11b: dark blue; DMSO17: orange; TCDD17: purple; DMSO11b: light green; TCDD1 1b: white. B: Samples re-grouped with regard to treatment (irrespective of passage number). DMSO: green; TCDD: red.

related to unsaturated acyl groups (signals 12,14 and 22 in Figure 1) due to allylic, bis-allylic and olefinic protons, respectively (average ratio TCDD: DMSO $=0.75$ ).

The NMR data suggested that fatty acid composition changed as a result of TCDD exposure. Therefore, a GC-MS analysis of the fatty acid composition was performed on the apolar fraction of the cells. Consistent with the ${ }^{1} \mathrm{H}$ NMR results, there was a difference in the apolar fractions of cells exposed to TCDD and DMSO with regard to the lipid content. Among the methyl esters of fatty acids that were identified, the arachidonic
(AA, C20:4, n-6) and docosahexaenoic (DHA, C22:6, n3) PUFAs had the same profile within the samples. The NMR data demonstrated that long chain PUFA content correlates highly with PL. Therefore, samples were normalized on the basis of the sum of the AA and DHA signals. This normalized dataset was subjected to MVA $\left({ }^{2} \log\right.$ transformation, ANOVA with $\mathrm{p}<0.01$, followed by a PCA; see Figure 4A). The PCA plot obtained was similar to that obtained for ${ }^{1} \mathrm{H}$ NMR.

In order to extract the most significant differences between the exposures, the samples were re-grouped
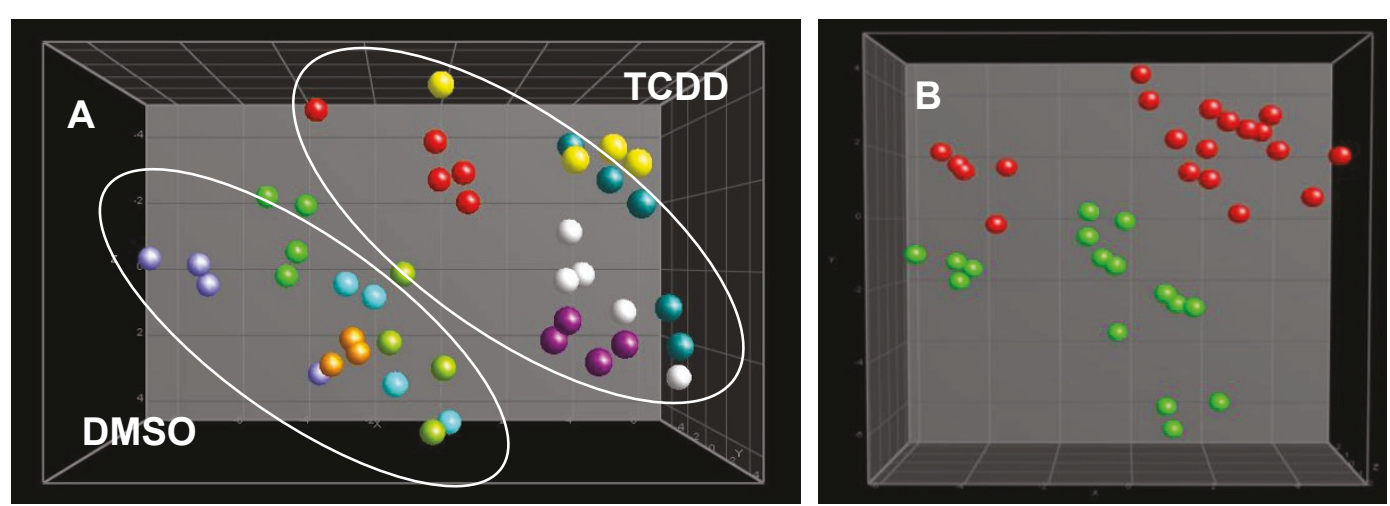

Figure 4 PCA plots (after ANOVA $p<0.01$ ) after normalization of the apolar fraction of HepG2 cells analyzed by GC-MS. A: Spheres with the same colour are technical replicates of the same sample per passage number. For denotation of the colours, see legend Figure 3. B: Samples re-grouped with regard to treatment (irrespective of passage number). DMSO: green; TCDD: red. 
with regard to the treatments and re-analyzed (PCA, after an ANOVA with $\mathrm{p}<0.01$; see Figure $4 \mathrm{~B}$ and in Additional File 1, Table S1).

The selection of peaks underlying the largest differences (and additionally surviving a Bonferroni correction) between the treatments were identified. Table 2 presents these fatty acids and their fold change and indicates that the content of several fatty acids decreased due to TCDD treatment. However, there was a slight increase in the proportion of saturated fatty acids with 17 (average ratio TCDD: DMSO $=1.2$ ) and 18 (average ratio TCDD: DMSO $=1.3$ ) carbon atoms, and an increase in the proportion of an unidentified C18:2 isomer (average ratio TCDD: DMSO $=1.3)($ Table 2$)$. The decrease in several unsaturated groups observed in the GC-MS data (Table 2) is in agreement with the NMR data.

\section{The polar fraction}

The ${ }^{1} \mathrm{H}$ NMR spectra of polar fractions were normalized using the $\mathrm{PL} / \mathrm{CHCl}_{3}$ ratio described above (obtained

Table 2 Apolar metabolites significantly affected by TCDD $(p<0.01)$ and average fold change ratio between treatments (TCDD vs. DMSO).

\begin{tabular}{|c|c|}
\hline GC-MS & Ratio TCDD/DMSO (RTD) \\
\hline C12:0 & 0.78 \\
\hline C14:0 & 0.72 \\
\hline $\mathrm{C} 14: 1_{\mathrm{a}}$ & 0.70 \\
\hline $\mathrm{C} 14: 1_{\mathrm{b}}$ & 0.29 \\
\hline C16:1 (n-6) & 0.63 \\
\hline C16:1 (n-9) & 0.62 \\
\hline $\mathrm{C} 17: 0$ & 1.20 \\
\hline C18:0 & 1.27 \\
\hline C18:1 (n-9) & 0.78 \\
\hline $\mathrm{C} 18: 1_{\mathrm{c}}$ & 0.72 \\
\hline $\mathrm{C} 18: \mathrm{z}_{\mathrm{a}}$ & 0.71 \\
\hline $\mathrm{C} 18: \mathrm{2}_{\mathrm{b}}$ & 0.63 \\
\hline $\mathrm{C} 18: 2_{c}$ & 1.29 \\
\hline$C 18: 2_{d}$ & 0.64 \\
\hline $\mathrm{C} 18: 2_{\mathrm{e}}$ & 0.63 \\
\hline $\mathrm{C} 20: 1_{\mathrm{b}}$ & 0.79 \\
\hline$C 20: 2_{a}$ & 0.74 \\
\hline $\mathrm{C} 20: 2_{b}$ & 0.70 \\
\hline$C 20: 3 a$ & 0.80 \\
\hline$C 20: 3_{b}$ & 0.64 \\
\hline C22:2 & 0.61 \\
\hline $\mathrm{C} 22: 3_{\mathrm{a}}$ & 0.73 \\
\hline${ }^{7} H N M R$ & Ratio TCDD/DMSO (RTD) \\
\hline Total triglycerides & 0.51 \\
\hline Total cholesterol ester & 0.69 \\
\hline
\end{tabular}

*Underscore letters indicate isomers (unidentified).

Individual passage number results are in Additional File 1 (Tables S3 and S4). from the corresponding apolar fractions) and presented in Figure 2B. Representative normalized ${ }^{1} \mathrm{H}$ NMR spectra replicates of polar extracts from HepG2 cells were overlaid (Figure 5) and the assignment of the signals is presented in Table 3. The normalized pre-processed and aligned NMR data were subjected to multivariate analysis and the output (PCA plot after ${ }^{2} \log$ transformation and ANOVA $\mathrm{p}<0.01$ ) is presented in Figure 6A. Differences between the polar fraction of cells exposed to TCDD and those exposed to the control can clearly be observed following the $\mathrm{x}$-axis of the PCA. The $y$-axis represents the differences between the different passage numbers. To identify effects due to TCDD treatment, an ANOVA ( $p<0.01)$ (after ${ }^{2} \log$ transformation) with regard to the treatment was performed, followed by PCA (Figure 6B). From the underlying peak loadings (additionally surviving a Bonferroni correction) responsible for the separation of samples in the PCA, it is possible to create a list of resonance positions that contribute significantly to the observed PCA separation.

The normalized NMR data indicated that the levels of several polar intracellular metabolites decreased due to exposure to TCDD (Table 4). However, the intensities of signals relating to taurine (average ratio TCDD: DMSO $=1.4$ ), citrate (average ratio TCDD: DMSO = 1.5), reduced glutathione, GSH (average ratio TCDD: DMSO = 1.6) and oxidized glutathione, GSSG (average ratio TCDD: DMSO = 1.3) increased. The GSH/GSSG ratio increased by $18 \%$ due to TCDD exposure.

The same extracts were analyzed by LC-MS in order to obtain more detailed information concerning the differences in polar metabolite levels due to treatment. The LC-MS data were pre-processed and aligned using MetAlign, the program developed in-house [34]. The aligned fingerprint data, in the form of generated spreadsheets, were normalized using the $\mathrm{PL} / \mathrm{CHCl} 3$ ratio and subjected to ${ }^{2} \log$ transformation and ANOVA with $\mathrm{p}<0.01$ followed by PCA (Figure 7A). The separation between samples was dominated by passage number rather than by treatment. In order to determine the effect of TCDD on the polar fraction of the cells, the samples of this dataset were re-grouped with regard to treatment, and an ANOVA $(\mathrm{p}<0.01)$ followed by a PCA was performed after ${ }^{2} \log$ transformation (Figure 7B). From the peak loadings (additionally surviving a Bonferroni correction) responsible for the separation of samples in this PCA, it is possible to create a list of masses that contributed significantly to the observed PCA separation. This list of masses was screened for molecular ions that showed at least a 1.2 fold change due to the treatment. Table 4 lists the metabolites and their fold change, as determined on the basis of fragmentation data from LC-nanomate-Orbitrap experiments. Table 5 presents the exact experimental masses 


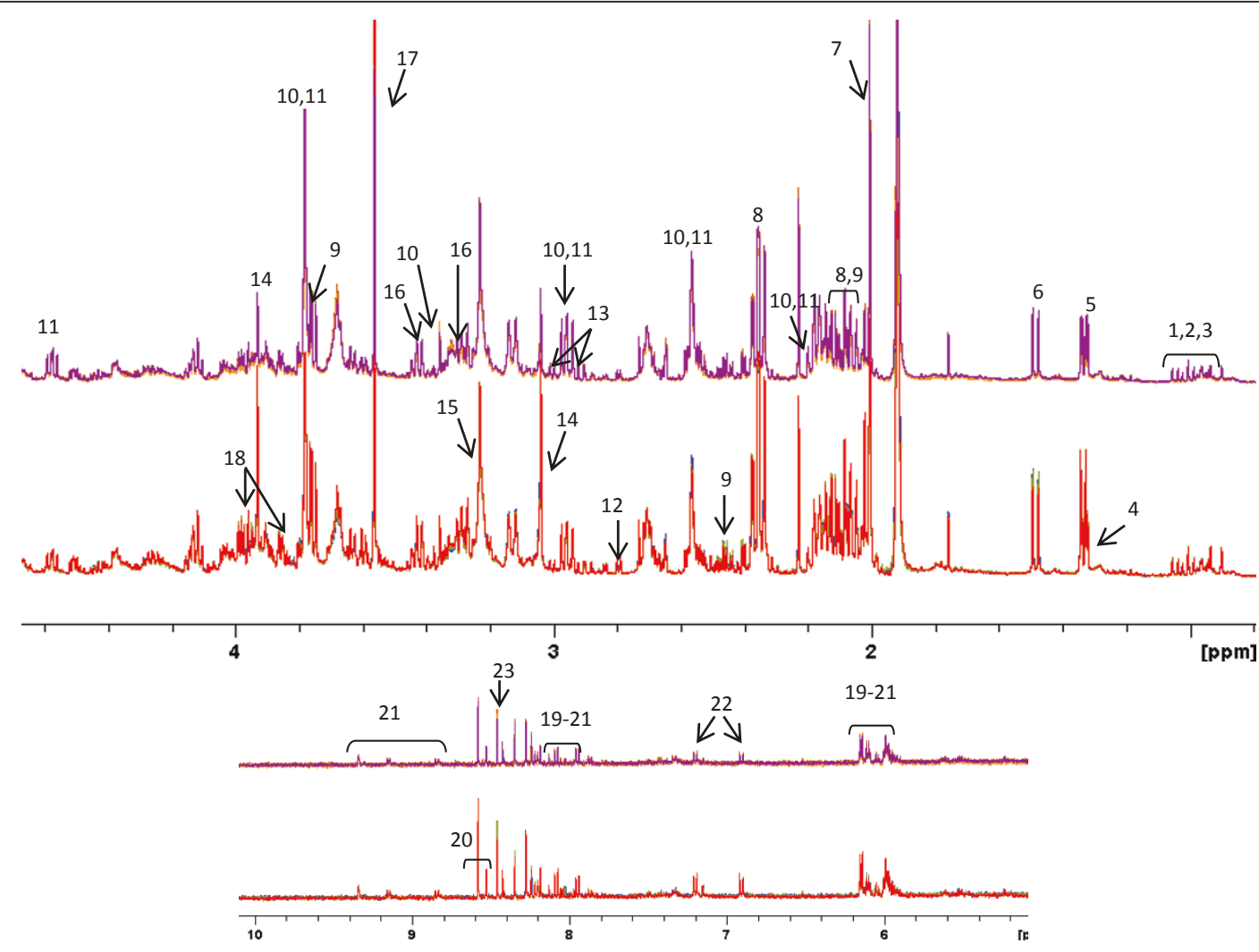

Figure $5{ }^{1} \mathrm{H}$ NMR spectra overlaid (4-fold) of the polar fraction of HepG2 cells exposed to DMSO (below) and TCDD (above). The following metabolites are identified by using standards, from the literature and/or databases and the numbers of the signals correspond to those indicated in Table 3. 1\&2: leucine and isoleucine; 3: valine: 4: threonine: 5: lactale; 6: alanine; 7: putrescine; 8: acetate; 9: N-acetyl-aspartate; 10: glutamate; 11: glutamine; 12: reduced glutathione; 13: oxidized glutathione; 14: acetone; 15: citric acid; 16: creatine and/or phosphocreatine; 17: choline derivatives; 18: taurine; 19: glycine; 20: serine; 21: nucleotides derived from uridine (UMP, UDP, UTP); 22: nucleotides derived from adenosine (AMP, ADP, ATP); 23: NAD+ and/or NADH; 24: tyrosine; 25: formate.

of these metabolites, together with their obtained fragments. A few metabolites remained unidentified.

There were significant increases in citric acid (average ratio TCDD: DMSO $=1.7$ ) and in GSSG (average ratio TCDD: $\mathrm{DMSO}=1.3$ ) and GSH (average ratio TCDD: DMSO $=1.2)$ contents in TCDD treated samples, in general agreement with the ${ }^{1} \mathrm{H}$ NMR data. However, the GSH/GSSG ratio as determined from LC-MS data was reduced, in contrast to the NMR data. Generally, NMR data are more quantitative and reliable; furthermore, the LC-MS data were acquired at a later date than the NMR data. In a follow-up NMR study on the stability of the sample, it was observed that the intensity of the GSH signal decreased over time during storage whereas the intensity of the GSSG signal increased (see Figure S1 in Additional File 1). No other metabolic changes were observed.

This reaction is known to be dependent on $\mathrm{pH}$ (i.e. more prominent at higher $\mathrm{pH}$ ). Therefore storage conditions such as $\mathrm{pH}$ are important. NMR samples were measured directly after adding phosphate buffer to the freshly made extracts. In this study the UPLC-TOF/MS samples were stored at $-20^{\circ} \mathrm{C}$ without the phosphate buffer and therefore under more acidic conditions $(\mathrm{pH}$ ca. 5 as a result of the extraction conditions). The maximum storage time before UPLC-TOF/MS measurement was 4 months. Under these storage conditions still some conversion to of GSH to GSSG was present as deduced from our experiments.

\section{Discussion}

The main aim of this study was to demonstrate the feasibility of using metabolomics on intracellular compounds of in vitro cell systems such as HepG2 cells, as an alternative approach to studying the effects of toxicants. We have demonstrated that reproducible results can be obtained and that differences between controls from different experiments can be subjected to statistical analysis, but that caution is required with regard to repeatability of experiments; generally, the same effects are observed in different experiments but their magnitudes can differ. However, there is a consistent effect 
Table 3 Assignment of ${ }^{1} \mathrm{H}$ NMR spectral signals of the polar fraction

\begin{tabular}{|c|c|c|}
\hline Peak number & Chemical shift (ppm) and multiplicity ${ }^{\mathrm{b}, \mathrm{c}}$ & Assignment $^{\mathrm{a}}$ \\
\hline 1 & $0.96(\mathrm{t})$ & Leucine \\
\hline 2 & $0.96,1.05(\mathrm{t})$ & Isoleucine \\
\hline 3 & $1.01,1.04(d)$ & Valine \\
\hline 4 & $1.32(d)$ & Threonine \\
\hline 5 & $1.33(d)$ & Lactate \\
\hline 6 & $1.48(d)$ & Alanine \\
\hline 7 & $2.00(s), 2.48(d d)$ & $\mathrm{N}$-acetyl-aspartate \\
\hline 8 & $2.08(\mathrm{~m}), 2.34(\mathrm{~m})$ & Glutamate \\
\hline 9 & $2.12(\mathrm{~m}), 2,44(\mathrm{~m}), 3.76(\mathrm{~m})$ & Glutamine \\
\hline 10 & $2.18(\mathrm{~m}), 2,57(\mathrm{~m}), 2.98(\mathrm{dd}), 3.31(\mathrm{dd}), 3.78(\mathrm{~m})$ & Oxidized glutathione \\
\hline 11 & $2.18(\mathrm{~m}), 2,57(\mathrm{~m}), 2.98(\mathrm{dd}), 3.78(\mathrm{~m}), 4.58(\mathrm{dd})$ & Reduced glutathione \\
\hline 12 & $2.80(\mathrm{dd})$ & Aspartate \\
\hline 13 & $2.55(d), 2.67(d)$ & Citrate \\
\hline 14 & $3.04(s), 3.93(d)$ & Creatine/Phosphocreatine \\
\hline 15 & $3.23(s)$ & Choline derivatives \\
\hline 16 & $3.26(t), 3.41(t)$ & Taurine \\
\hline 17 & $3.56(s)$ & Glycine \\
\hline 18 & $3.83(d d), 3.98(d d)$ & Serine \\
\hline 19 & $6.10(\mathrm{~d}), 6.14(\mathrm{~d}), 8.18-8.22(\mathrm{ov}), 8.52(\mathrm{~s}), 8.58(\mathrm{~s})$ & Nucleotides derived from adenosine AXP (AMP, ADP and/or ATP) \\
\hline 20 & 5.95-5.99 (ov), 7.94-7.97 (ov), 8.09 (d) & Nucleotides derived from uridine UXP (UMP, UDP and/or UTP) \\
\hline 21 & $6.01-6.20$ (ov), 8.12-8.20 (ov), 8.79-8.88 (ov), 9.08-9.36 (ov) & Nicotinamide adenine dinucleotides (NAD, NADH, NADP and/or NADPH) \\
\hline 22 & $6.99(m), 7.20(m)$ & Tyrosine \\
\hline 23 & $8.46(\mathrm{~s})$ & Formate \\
\hline
\end{tabular}

Numbers correspond with those in Figure 5.

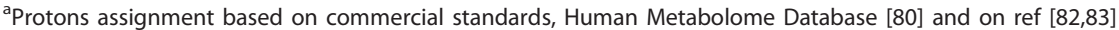

${ }^{\mathrm{b}}$ s: singlet; d: doublet; dd: doublet/doublet; m: multiplet; ov: different overlapping signals

'Only observed signals are shown

(due to TCDD in this study) on metabolic profiles using an untargeted approach. The changes in metabolite concentrations are minimal and can vary because of the effect of the treatment on cell numbers. Therefore, normalization (using PL and PUFA), as described above, is crucial; so is having enough biological replicates to ensure the accuracy of the data. Without normalization or sufficient biological replicates, several of the metabolic changes may not have been detected. In apparent contradiction to the normalization using PL, it has been reported that TCDD induces the expression of the phospholipase A2 $\alpha$ (PLA2 $\alpha$ ) gene in mouse hepatoma Hepa1c1c7 [35]. However, in this HepG2 study, degradation of PL was not evident with regard to total PL. Furthermore, a parallel study using transcriptomics did not provide evidence of an effect of TCDD on PLA2 $\alpha$ gene expression in HepG2 cells; this supports the present findings for HepG2 cells and supports the validity of the chosen normalization method.

To substantiate the usefulness of the untargeted metabolomics methodology, the observed changes in metabolite levels were interpreted in the light of published data concerning the effect of TCDD. Ultimately, this was the validation of the procedures and protocols developed in this study. In general, a decrease or increase of an intracellular metabolite concentration is not necessarily an indicator of flux. Actual metabolite levels depend on how biochemical pathways/processes are regulated, how metabolites in pathways interact and how fast and in which directions reactions occur (kinetics). Cells tend to balance their metabolism after perturbation in order to maintain homeostasis. Therefore, it is likely that only changes in the main pools of substrates in the cell are measured when it is exposed to a toxicant. Inhibition/ activation of a pathway may lead to increased or decreased levels of relevant pools of compounds. However, it is often difficult to determine whether inhibition or activation is relevant by observing metabolite concentrations at one time point. As discussed in more detail below, TCDD is known to have an effect on the proliferative capacity, metabolism and antioxidant status of the cell.

\section{Effect on cell proliferation}

Membrane constituents such as PL (Figure 2B) and free cholesterol are present at lower levels in extracts obtained after treatment with TCDD because there are fewer cells in the culture, and are indicative of decreased 

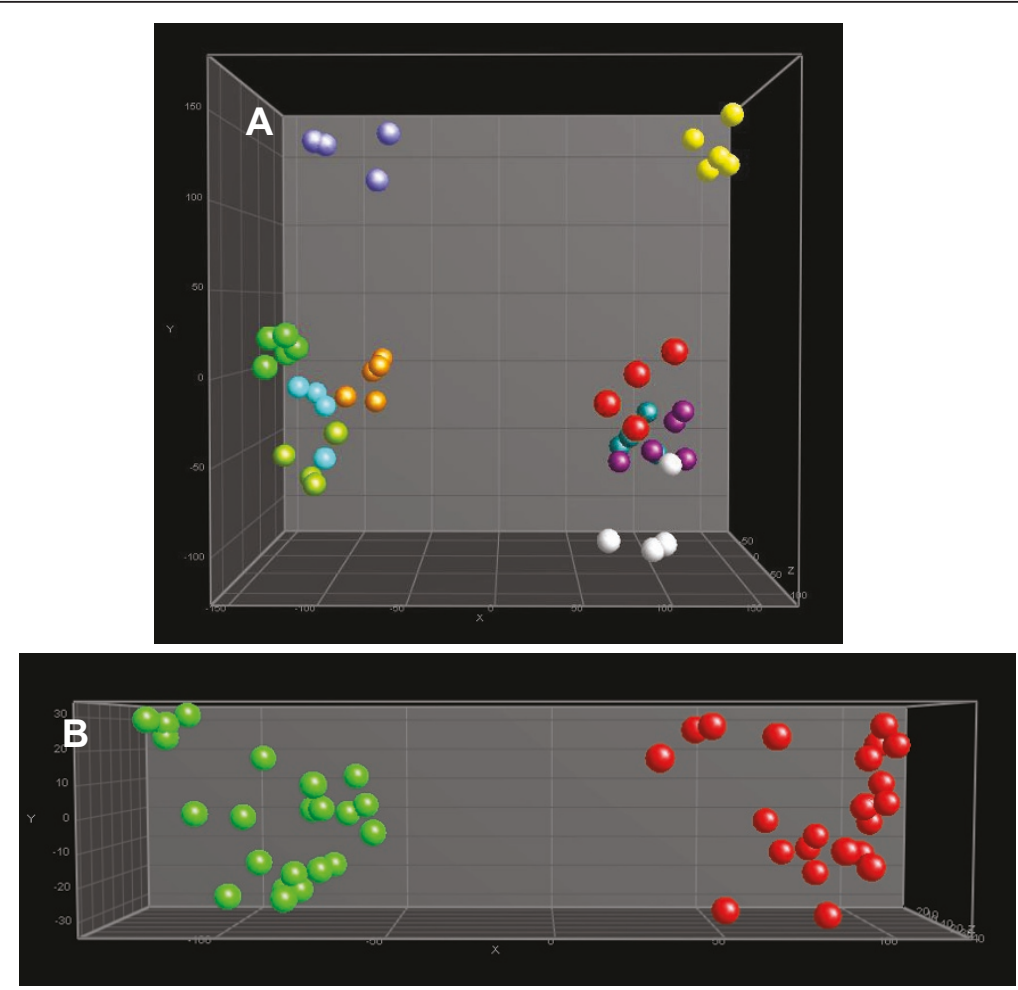

Figure 6 PCA plots (after ANOVA $\mathrm{p}<0.01$ ) after normalization of the polar fraction of HepG2 cells analyzed by ${ }^{1} \mathrm{H}$ NMR and preprocessed and aligned using a program developed in-house. A: Spheres with the same colour are technical replicates of the same sample per passage number. For denotation of the colours, see legend to Figure 3. B: Samples re-grouped with regard to treatment (irrespective of passage number). DMSO: green; TCDD: red..

proliferation during exposure; the anti-proliferative effect of TCDD has been described previously [26]. The lower levels of nucleotides in treated extracts indicate a change in metabolites known to be involved in DNA synthesis (Table 4).

Spermidine and N1-acetylspermidine were also found in lower levels after TCDD treatment. Polyamines have important functions in cell proliferation, differentiation and apoptosis, and they are essential for hepatic growth and regeneration [36]. Polyamines can be synthesized in liver from agmatine (formed by decarboxylation of arginine, via arginine decarboxylase) [37], but ornithine decarboxylase (ODC) is the main enzyme responsible for polyamine biosynthesis. ODC is involved in the conversion of ornithine into putrescine, the precursor of other polyamines $[38,39]$. Their catabolism, on the other hand, is regulated by the enzymatic action of the polyamines spermidine/spermine N1-acetyltransferase (cSAT) and diamine oxidase [40].

ODC is induced during conditions where there is enhanced gene activation and tissue growth. It has been reported that ODC induction is inhibited by TCDD $[38,39]$.
Therefore, it is possible that induction of polyamine synthesis in cultured HepG2 cells was inhibited by TCDD, resulting in the low content of spermidine.

\section{Effect on metabolism}

Changes in metabolic profiles due to TCDD treatment of HepG2 cells indicates major changes in the general metabolism of these cells, which involves fatty acids, amino acids and nucleotides. This is reminiscent of wasting syndrome [21,41-43].

The decreases in triglycerides, cholesterol ester and unsaturated fatty acids observed in the ${ }^{1} \mathrm{H}$ NMR analysis of the apolar fraction, together with the decreases in several fatty acids observed in the GC-MS data, indicate that under the conditions used in this study, TCDD affected lipid metabolism.

Several in vivo studies [44-46] have demonstrated that TCDD reduces the activity of enzymes involved in the synthesis of de novo fatty acids (such as fatty acid synthase, FAS and acetyl CoA carboxylase, AAC) and in cholesterol biosynthesis (such as 3-hydroxy-methylglutaryl-CoA synthase) or the expression of genes encoding these enzymes $[41,42,47-49]$. This effect, which was also 
Table 4 Polar metabolites significantly affected by TCDD exposure.

\begin{tabular}{|c|c|c|}
\hline Metabolite & Change fold ( ${ }^{1} H$ NMR $\left.p<0.01\right)$ & Change fold (LC-MS $p<0.01$ ) \\
\hline Leucine, Isoleucine & 0.69 & 0.64 \\
\hline Valine & 0.72 & 0.69 \\
\hline Alanine & 0.68 & - \\
\hline $\mathrm{N}$-acetyl-aspartate & 0.68 & 0.72 \\
\hline Glutamate & 0.79 & 0.80 \\
\hline Glutamine & 0.69 & - \\
\hline Glycine & 0.72 & - \\
\hline Aspartate & 0.66 & - \\
\hline Serine & 0.65 & - \\
\hline Tyrosine & 0.58 & 0.44 \\
\hline Proline & - & 0.54 \\
\hline Tryptophan & - & 0.79 \\
\hline Lactate & 0.49 & - \\
\hline Spermidine & - & 0.24 \\
\hline N1-acetyl-spermidine & - & 0.59 \\
\hline Pantothenic acid & - & 0.62 \\
\hline Creatine/Phosphocreatine & 0.66 & - \\
\hline Propyonylcarnitine $^{\mathrm{b}}$ & - & 0.66 \\
\hline Butyrylcarnitine & - & 0.58 \\
\hline Nucleotides (AXP and UMP) & $0.3-0.6$ & - \\
\hline UMP & - & 0.71 \\
\hline AMP & - & 0.67 \\
\hline Oxidized glutathione & 1.26 & 1.31 \\
\hline Reduced glutathione & 1.58 & 1.23 \\
\hline Taurine & 1.37 & - \\
\hline Citrate & 1.46 & 1.68 \\
\hline UDP-N-acetyl-galactosamine/glucosamine* & - & 1.48 \\
\hline
\end{tabular}

The fold changes are given as the ratio of the average content in TCDD and in DMSO. Individual passage number results are in Additional File 1 (Tables S5 and S6).

*Tentatively identified

observed in experiments using mouse embryo fibroblasts [50], supports the results presented here. In studies carried out in vivo [49] and in vitro [50], it has been reported that the effect of TCDD on the gene expression of enzymes involved in the de novo synthesis of fatty acids is mediated by AhR.

Using GC-MS analysis it is possible to determine the nature of the fatty acids that are most affected by exposure to TCDD (Table 2). The levels of the majority of fatty acids decreased upon treatment. However, the contents of heptadecanoic (C17:0) and octadecanoic, i.e. stearic (C18:0), acids were increased after exposure. The increased percentage of saturated and the decreased percentage of mono-unsaturated fatty acids could be due to the decreased expression of stearoyl-CoA-desaturase (SCD1), as demonstrated in mouse embryo fibroblasts after TCDD exposure [51]. SCD1 is the rate limiting enzyme in the biosynthesis of mono-unsaturated fatty acids and catalyzes the introduction of the cis double bond in the $\Delta 9$ position of acyl CoA substrates [52].
Therefore, inhibiting the expression of SCD1 using TCDD would partially explain the increased ratio between saturated/monounsaturated fatty acids observed in this study.

Pantothenic acid and AMP are metabolites found in lower concentrations after exposure to TCDD (Table 4). Pantothenic acid and AMP are two of the three precursors for coenzyme A (CoA) synthesis. In general, during fatty acid degradation and synthesis, CoA transports fatty acids as acyl groups through repetitive degradative or synthetic cycles.

Furthermore, decreases in the content of propionyland butyryl-carnitines were observed when cells were exposed to TCDD. These short chain acyl-carnitines are metabolic products of the reaction of acyl CoA and carnitine, which is mediated by transferases in the mitochondria [53]. Formation of butyryl- and propionylcarnitines is favored when butyryl and propionyl-CoA accumulate in the mitochondria owing to an increased acyl-CoA/CoA ratio. In the case of propionyl-CoA, an 


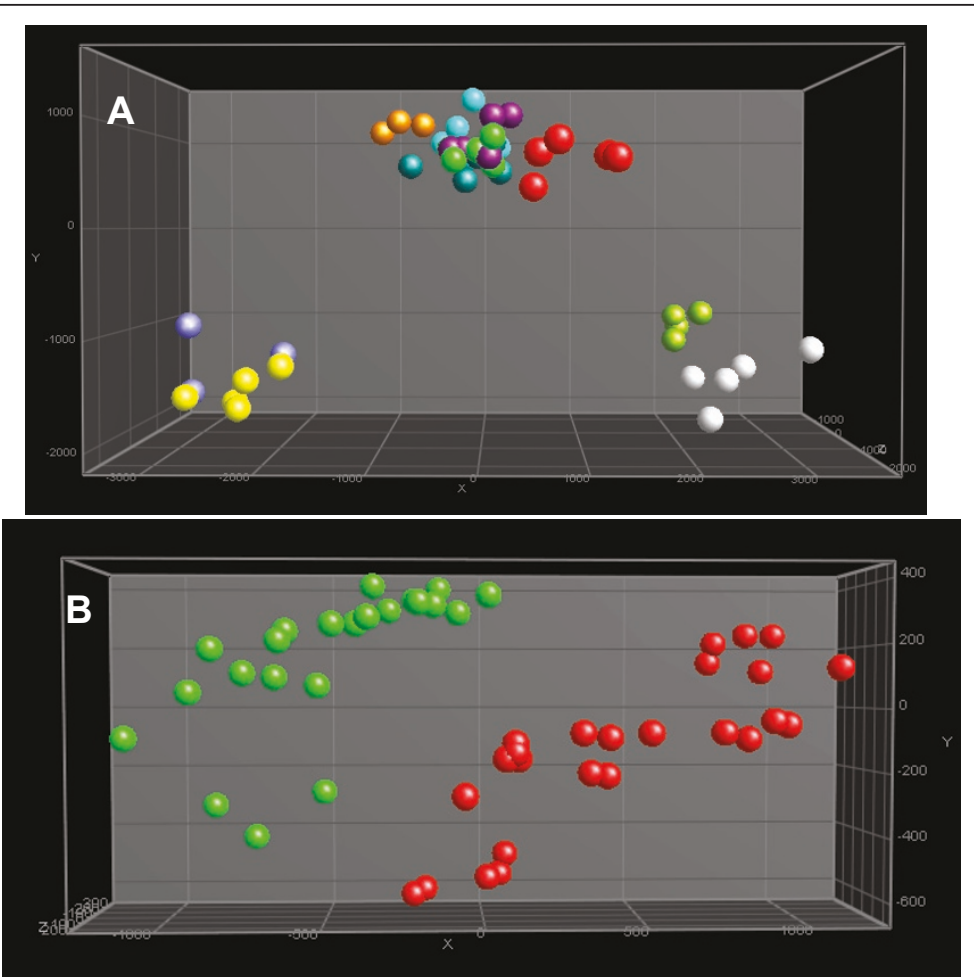

Figure 7 PCA plots (after ANOVA $p<0.01$ ) after normalization of the polar fraction of HepG2 cells analyzed by LC-ToF-MS and preprocessed and aligned using MetAlign (www.metalign.nl). A: Spheres with the same colour are technical replicates of the same sample per passage number. For denotation of the colours, see legend Figure 3. B: Samples re-grouped with regard to treatment (irrespective of passage number). DMSO: green; TCDD: red.

increase in the catabolism of amino acids such as valine, isoleucine and - indirectly - threonine and methionine also favors its formation [54]. Changes in these carnitine derivatives indicate that mitochondrial activity and transport across mitochondrial membranes is affected by CoA modulation and/or beta-oxidation of fatty acids.

The level of citrate increased, whereas the level of lactate decreased, after exposure. Citrate is a feedback inhibitor for glycolysis at the level of phosphofructokinase. Lactate is a product of the conversion of pyruvate by lactate dehydrogenase. These two metabolite changes can indicate that glycolytic activity is lower because of an influx of acetyl-CoA, for instance due to fatty acid beta-oxidation. This is in agreement with the breakdown of triglycerides and degradation of fatty acids, and changed activity in mitochondria (see above).

Together, these metabolic effects are reminiscent of a wasting syndrome in which fatty acid metabolism and energy metabolism (glycolysis, TCA cycle) are affected, and the amino acid and nucleic acid pools are reduced. These latter effects could contribute to the observed decrease in cell proliferation. However, it is not clear from the data whether beta-oxidation increased or if fatty acids were transported out of the cell. In adipose tissue, TCDD mobilizes fatty acids towards the plasma
[41,42,46,55,56]. An increase in amino acids circulating in plasma owing to TCDD exposure has previously been reported [57]. Therefore, the data could imply a shutdown of the cells followed by the export of several metabolites.

Several in vivo studies demonstrate an accumulation of lipids in the liver $[21,46,55,58]$, although the effects of TCDD vary depending on the dose, exposure-time or test animal used $[41,44,45,59]$. An increase in liver lipid content is in contrast to the results found in this research. However, in the published studies, a loss in body fat is demonstrated, as is an increase in the serum lipid content $[41,42,46,55,56]$. The increased serum lipid content could increase uptake and accumulation of extrahepatic lipids in liver $[46,60]$. This would explain the occurrence of a fatty liver in vivo, and the differences in terms of lipid content between in vivo and in vitro studies.

\section{Effect on antioxidant status}

NMR and LC-MS spectra demonstrated an increase in reduced (GSH) and oxidized (GSSG) glutathione content in samples treated with TCDD (Table 4). However, it has been reported that GSH content decreases after exposure to TCDD [61]. Furthermore, from the ${ }^{1} \mathrm{H}$ 
Table 5 Masses and fragments of the masses of polar metabolites identified by means of LC-nanomate-Orbitrap

\begin{tabular}{|c|c|c|c|c|}
\hline Compound & Parent mass $(M+1)^{1}$ & $\begin{array}{l}\text { Neutral } \\
\text { formula }\end{array}$ & Deviation $(\mathrm{mDa})^{1}$ & Fragments $^{1}$ \\
\hline \multirow[t]{2}{*}{ Proline } & 116.07046 & $\mathrm{C}_{5} \mathrm{H}_{9} \mathrm{NO}_{2}$ & -0.145 & 70.0649 \\
\hline & & & & 86.0961 \\
\hline \multirow[t]{2}{*}{ Leucine/Isoleucine } & 132.10191 & $\mathrm{C}_{6} \mathrm{H}_{13} \mathrm{NO}_{2}$ & 0.005 & 69.0696 \\
\hline & & & & 72.0805 \\
\hline \multirow[t]{2}{*}{ Spermidine } & 146.16503 & $\mathrm{C}_{7} \mathrm{H}_{19} \mathrm{~N}_{3}$ & -0.144 & 112.1117 \\
\hline & & & & 158.0443 \\
\hline \multirow[t]{3}{*}{ N-acetyl-aspartate } & 176.05542 & $\mathrm{C}_{6} \mathrm{H}_{9} \mathrm{NO}_{5}$ & 0.091 & 134.0444 \\
\hline & & & & 88.0390 \\
\hline & & & & 165.0542 \\
\hline \multirow[t]{3}{*}{ Tyrosine } & 182.08118 & $\mathrm{C}_{9} \mathrm{H}_{11} \mathrm{NO}_{3}$ & 0.010 & 136.0754 \\
\hline & & & & 119.0489 \\
\hline & & & & 72.0806 \\
\hline \multirow[t]{3}{*}{ Acetyl spermidine } & 188.17580 & $\mathrm{C}_{9} \mathrm{H}_{21} \mathrm{~N}_{3} \mathrm{O}$ & 0.061 & 17.1019 \\
\hline & & & & 171.1487 \\
\hline & & & & 188.0702 \\
\hline \multirow[t]{3}{*}{ L-tryptophan } & 205.09717 & $\mathrm{C}_{11} \mathrm{H}_{12} \mathrm{~N}_{2} \mathrm{O}_{2}$ & 0.016 & 146.0597 \\
\hline & & & & 118.0648 \\
\hline & & & & 193.0339 \\
\hline \multirow[t]{3}{*}{ Citric acid $\left(\mathrm{NH}^{+}\right)$} & 210.0606 & $\mathrm{C}_{6} \mathrm{H}_{8} \mathrm{O}_{7}\left(+\mathrm{NH}_{3}\right)$ & 0.002 & 175.0233 \\
\hline & & & & 129.0179 \\
\hline & & & & 173.0804 \\
\hline \multirow[t]{2}{*}{ Propionylcarnitine } & 218.13869 & $\mathrm{C}_{10} \mathrm{H}_{19} \mathrm{NO}_{4}$ & 0.005 & 155.0699 \\
\hline & & & & 202.1070 \\
\hline \multirow[t]{3}{*}{ Pantothenic acid } & 220.11792 & $\mathrm{C}_{9} \mathrm{H}_{17} \mathrm{NO}_{5}$ & -0.029 & 184.0963 \\
\hline & & & & 90.0547 \\
\hline & & & & 100,0754 \\
\hline \multirow[t]{3}{*}{ Unknown ${ }^{2}$} & 230.18622 & $\mathrm{C}_{11} \mathrm{H}_{24} \mathrm{O}_{2} \mathrm{~N}_{3}$ & -0.084 & 183.1121 \\
\hline & & & & 213.1520 \\
\hline & & & & 173.0802 \\
\hline Butyrylcarnitine & 232.15416 & $\mathrm{C}_{11} \mathrm{H}_{21} \mathrm{NO}_{4}$ & -0.175 & 85.0281 \\
\hline Unknown $^{2}$ & 250.03784 & $\mathrm{C}_{6} \mathrm{H}_{12} \mathrm{O}_{3} \mathrm{~N}_{4} \mathrm{P}_{2}$ & -0.075 & - \\
\hline \multirow[t]{4}{*}{ Unknown $^{2}$} & 258.11020 & $\mathrm{C}_{8} \mathrm{H}_{20} \mathrm{O}_{6} \mathrm{NP}$ & 0.100 & 104.1067 \\
\hline & & $\mathrm{C}_{7} \mathrm{H}_{14} \mathrm{ON}_{8} \mathrm{P}$ & 0.104 & \\
\hline & & & & 179.0414 \\
\hline & & & & 162.0216 \\
\hline \multirow[t]{2}{*}{ Glutathione reduced } & 308.09103 & $\mathrm{C}_{10} \mathrm{H}_{17} \mathrm{~N}_{3} \mathrm{O}_{6} \mathrm{~S}$ & -0.052 & 144.0110 \\
\hline & & & & 116.0161 \\
\hline \multirow[t]{2}{*}{ UMP } & 325.04318 & $\mathrm{C}_{9} \mathrm{H}_{13} \mathrm{~N}_{2} \mathrm{O}_{9} \mathrm{P}$ & 0.037 & 97.0281 \\
\hline & & $\mathrm{C}_{10} \mathrm{H}_{14} \mathrm{~N}_{5} \mathrm{O}_{7} \mathrm{P}$ & 0.001 & 136.0615 \\
\hline \multirow[t]{2}{*}{ AMP } & 348.07036 & & & 119.0349 \\
\hline & & & & 296.0650 \\
\hline Unknown & 425.10794 & - & - & 350,0753 \\
\hline \multirow[t]{2}{*}{ UDP-N-acetyl-galactosamine/glucosamine ${ }^{2}$} & 608.08866 & $\mathrm{C}_{17} \mathrm{H}_{27} \mathrm{~N}_{3} \mathrm{O}_{17} \mathrm{P}_{2}$ & -0.186 & 405.0079 \\
\hline & & & & 204.0861 \\
\hline Glutathione oxidized & 613.15906 & $\mathrm{C}_{20} \mathrm{H}_{32} \mathrm{~N}_{6} \mathrm{O}_{12} \mathrm{~S}_{2}$ & -0.178 & - \\
\hline
\end{tabular}

${ }^{1}$ Experimental value obtained in our measurements

${ }^{2}$ Tentatively assigned formula(e) and/or identification 
NMR data, it was observed that the GSH/GSSG ratio increased ca. 20\% with TCDD exposure. This ratio, considered a parameter for measuring the oxidative status of a cell, has been reported to decrease in several in vivo studies as a consequence of exposure to TCDD [23,61]. However, data are variable and some authors have reported an increase in the GSH/GSSG ratio after mice were treated with TCDD [22].

GSH acts as a nucleophilic "scavenger" of numerous compounds and their metabolites via enzymatic and chemical mechanisms (converting electrophilic centers to thioether bonds) and as a substrate in the glutathione peroxidase (GPx)-mediated reduction of lipid hydroperoxides and of $\mathrm{H}_{2} \mathrm{O}_{2}$ to water $[62,63]$. As a consequence of this reaction, GSH is oxidized to GSSG, which is in turn recycled back to GSH via glutathione reductase (GR). Therefore, any effect on the activity of GPx, GR or both could affect the ratio between GSH and GSSG. Several in vivo [61] and in vitro $[64,65]$ studies have described the inhibition of GPx activity in liver due to TCDD treatment. Inhibition of the activity of this enzyme could theoretically lead to an increase in the content of GSH and in the GSH/ GSSG ratio, as observed herein. However, it has been reported that the activity of GPx in liver mitochondria of mice exposed to TCDD is increased [22], but increased activity of GR in liver mitochondria was also evident, possibly explaining the increased GSH/GSSG ratio following dioxin treatment. Some studies have demonstrated that TCDD increases the activity of GR in liver cells [66], whereas other authors describe the opposite effect [64].

In relation to the synthesis of GSH, Boverhof and coauthors [41] demonstrated up-regulated expression of the genes for enzymes involved in the synthesis of GSH (such as glutamate-cysteine ligase, Gclc, and glutathione synthase, Gss) after rats and mice were exposed to TCDD. Increased synthesis of GSH could explain the results. Boverhof and co-authors [41] described a downregulation of the genes associated with the metabolism of glutamate and glycine, which are building blocks of GSH. They suggested that this down-regulation could be an adaptation of the cell to conserve these amino acids for increased glutathione synthesis.

\section{Other effects associated with TCDD treatment}

Creatine is decreased in cells as a result of TCDD treatment (Table 4). In relation to this, Boverhof and coauthors [41] found that genes expressing guanidinoacetate $\mathrm{N}$-methyltransferase (GAMT), one of the key enzymes in the biosynthesis of creatine, are down-regulated in liver after TCDD administration to rats. It has been reported that GAMT deficiency is associated with a reduction in body weight owing to reduced body fat mass [67], which could be related to the aforementioned in vivo effects of TCDD exposure.
The content of taurine, a non-protein sulfur-containing $\beta$-amino acid, is increased after the exposure of cells to TCDD. Taurine plays an important role in several biological processes including anti-oxidation, detoxification, membrane stabilization and maintenance of osmolarity [68]. Moreover, it has been demonstrated that there is a relationship between taurine and lipid metabolism $[69,70]$. Taurine lowers hepatic triglyceride concentration, reduces the synthesis of cellular cholesterol ester and elevates hepatic free fatty acids. These effects are in agreement with the results of the present study for HepG2 cells exposed to TCDD. TCDD down-regulates cysteine dioxygenase (CDO) $[41,42,71,72]$, the first enzyme in the conversion of cysteine to taurine. This seems to conflict with the observation of higher taurine levels after exposure to TCDD, but since the regulation of taurine concentration is unknown, perhaps the increased concentration of taurine after exposing cells to TCDD is related to other mechanisms.

An increased signal (average ratio TCDD: DMSO = 1.5) tentatively assigned to uridine diphosphate- $\mathrm{N}$-acetylgalactosamine (UDP-NAcGal) and/or uridine diphosphate- $\mathrm{N}$-acetylglucosamine (UDP-NacGlu) was observed after TCDD exposure (Table 4).

UDP-NAcGal and UDP-NacGlu are N-acetylhexosamines involved in several biosynthetic reactions including $\mathrm{O}$-glycosylation of proteins on serine and threonine residues. O-linked glycosylation involves the transfer of the $\mathrm{N}$-acetylhexosamine group from the UDP-acetylhexosamine, which is catalyzed by glycosyltransferases $[73,74]$.

Lower activity of these enzymes could theoretically produce an increase in the levels of UDP-N-acetylhexosamines. In agreement with this, decreased expression of GALNT1, the gene encoding the UDP-N-acetylgalactosamine transferase, was observed by Kim and co-authors [75] after HepG2 cells were exposed to TCDD.

Changes in the intracellular levels of UDP-N-acetylhexosamines, as observed in this study after exposure to TCDD, may indicate that protein O-glycosylation is affected. Altered expression levels of glycosylated protein have been described after TCDD exposure in vitro [76].

We have no explanation for the decrease in concentration of $\mathrm{N}$-acetyl aspartate. This metabolite is normally expressed at high concentrations in the brain and has been implicated as an osmolyte [77] with the potential to bind to calcium ions or metal ions [78].

\section{Conclusions}

The present study demonstrates that untargeted profiling of the polar and apolar extracts of in vitro cultured HepG2 cells using various analytical techniques is a feasible approach to studying the effect of a toxicant, 
TCDD, on the cell metabolome. In the metabolomics methodology used, sample protocols and handling were minimized to enhance reproducibility. The results are compatible with previously well-documented effects of TCDD, in vitro and in vivo. This serves to validate the metabolomics results produced in this study. This combination of cell culture and metabolomics technology (together with other -omics techniques) can contribute to reducing the number of animals required for toxicity studies.

This study is an example of how complementary analytical techniques (NMR, GCMS, LCMS) can be used on the same samples and provide complementary data. The untargeted nature of the experiments aids in finding differences in profiles, which are then subjected to identification approaches. As discussed, normalization and sufficient biological replicates (and repeated experiments) are essential for reliability (in terms of statistical analysis) in detecting relatively small differences in analyte concentrations.

Maintaining homeostasis could be the driving force in cells responsible for keeping concentration differences small. The effects are predominantly centered on storage pools of metabolites.

\section{Methods}

\section{Chemicals}

Minimal essential medium (MEM glutamax), non-essential amino acids, sodium pyruvate, penicillin/streptomycin and fetal bovine serum were purchased from Gibco BRL (Breda, The Netherlands). Ammonium acetate $\left(\mathrm{NH}_{4} \mathrm{Ac}\right)$, sodium hydroxide $(\mathrm{NaOH})$, sodium chloride $(\mathrm{NaCl})$, dipotassium hydrogenphosphate $\left(\mathrm{K}_{2} \mathrm{HPO}_{4}\right)$, monopotassium hydrogenphosphate $\left(\mathrm{KH}_{2} \mathrm{PO}_{4}\right)$, boron trifluoride $\left(\mathrm{BF}_{3}\right)$, EDTA and deuterated chloroform $\left(\mathrm{CDCl}_{3}\right)$, deuterium oxide $\left(\mathrm{D}_{2} \mathrm{O}\right)$ and deuterated methanol $\left(\mathrm{CD}_{3} \mathrm{OD}\right)$ were obtained from Merck (Darmstadt, Germany); methanol (MeOH) and iso-octane from Biosolve (Valkenswaard, The Netherlands); DMSO and TMSP from Sigma-Aldrich (St. Louis, MO, USA) and TCDD (CAS no. 1746-01-6) from Cerilliant (Round Rock, TX, USA). All chemicals and solvents were purchased in the highest purity available. Ultra-pure water was obtained using the PureLab equipment from Rossmark (Ede, The Netherlands).

\section{Cell culture treatment and disruption}

HepG2 cells were obtained from the ATCC (Rockville, MD) and cultured in MEM glutamax supplemented with $1 \%$ non-essential amino acids, $1 \%$ sodium-pyruvate, $1 \%$ penicillin/streptomycin and $10 \%$ fetal bovine serum (FBS). The cells were incubated at $37^{\circ} \mathrm{C}$ with $5 \% \mathrm{CO}_{2}$. When the cell monolayer reached $80 \%$ confluency, the medium was replaced with fresh medium with or without TCDD. TCDD was administered to a final concentration of $10 \mathrm{nM}$ by adding $60 \mu \mathrm{l}$ of a solution of 2 $\mu \mathrm{M}$ of TCDD in DMSO to $12 \mathrm{ml}$ of medium. In the control treatments, cells were exposed to $12 \mathrm{ml}$ of medium to which $60 \mu \mathrm{l}$ of DMSO had been added. The final concentration of $10 \mathrm{nM}$ TCDD was sub-cytotoxic and has been used in previous omics studies $[1,15]$ The treatment of HepG2 cells with $10 \mathrm{nM}$ TCDD and the vehicle control (DMSO) was terminated after $48 \mathrm{~h}$ (as in previous studies) by washing the cells several times with ice-cold $0.9 \% \mathrm{NaCl}$ in ultra-pure water and disrupting them by osmotic shock with ice-cold ultra-pure water. The cells were harvested using a cell scraper and subsequently treated ultrasonically to ensure total disruption. The TCDD effect on the cell metabolome was studied in five independent experiments, using five different passage numbers $(p+7, p+11 a, p+11 b, p+17$ and $p+30)$. All cells, except those in $\mathrm{p}+11 \mathrm{~b}$, originally came from the same cryogenic vial; those in $\mathrm{p}+11 \mathrm{~b}$ were obtained from a second vial of frozen cells in order to check whether there were differences between the same passage numbers from different vials $(\mathrm{p}+11 \mathrm{a} v s . \mathrm{p}+11 \mathrm{~b})$. Four independent biological replicates (i.e. tissue culture flasks) were examined in each experiment.

A separate study - prior to this one - with additional replicates was done to establish the suitability of the normalization approach based on PL signals. This study involved cell counting. In short, the cells were detached from the flasks by trypsinization and counted using a hemocytometer (Neubauer chamber). The results are given in Table S2, Additional File 1.

\section{Extraction of the apolar and polar fractions}

The metabolomics study was performed on two different fractions of the cells, one apolar fraction containing the apolar metabolites (membranes and intracellular lipids), and one polar fraction, containing the polar and semi-polar intracellular metabolites. To extract these, the disrupted cells were centrifuged $\left(4^{\circ} \mathrm{C}\right)$ and the pellet (apolar fraction) and supernatant (polar fraction) were separated and processed.

\section{Apolar fraction}

The pellet was re-suspended in $1 \mathrm{M} \mathrm{NH}_{4} \mathrm{Ac}$ and freezedried. Once dried, the residue was extracted three times with $1 \mathrm{ml}$ of $\mathrm{CDCl}_{3}$, after which the organic solvent was evaporated under $\mathrm{N}_{2}$ flow. The dried extract was dissolved in $1 \mathrm{ml}$ of $\mathrm{CDCl}_{3}$; an aliquot $(0.6 \mathrm{ml})$ was used for NMR analysis and the remaining sample was stored at $-20^{\circ} \mathrm{C}$ for GC-MS analysis.

\section{Polar fraction}

The supernatant containing the polar intracellular metabolites was freeze-dried. The pellet was re-suspended in $1 \mathrm{ml}$ of $100 \% \mathrm{CD}_{3} \mathrm{OD}$, dried with $\mathrm{N}_{2}$ and re-suspended in $50 \% \mathrm{CD}_{3} \mathrm{OD} / 50 \% \mathrm{D}_{2} \mathrm{O}$. The solution was centrifuged 
to remove the proteins (in the pellet) and the supernatant was dried under $\mathrm{N}_{2}$ flow. The dry residue was dissolved in $1 \mathrm{ml}$ of $\mathrm{D}_{2} \mathrm{O}$. Some of the sample $(350 \mu \mathrm{l})$ was stored at $-20^{\circ} \mathrm{C}$ for UPLC-TOF/MS analysis. To the remainder, $1 \mathrm{M}$ phosphate buffer (90:10; v: v; $\mathrm{pH}=7$ ) in $99.95 \% \mathrm{D}_{2} \mathrm{O}$ was added and used for NMR analysis.

\section{Analysis of the polar and apolar fractions NMR analysis}

The samples were analyzed by NMR just after extraction. Some of these samples were also used for a followup study with the aim of determining the stability of the different metabolites over time. These samples were stored at $-20^{\circ} \mathrm{C}$ in phosphate buffer $(\mathrm{pH}=7)$ for 9 months.

The ${ }^{1} \mathrm{H}$ NMR spectra were recorded at $400.13 \mathrm{MHz}$ at $300.0( \pm 0.05) \mathrm{K}$ on a Bruker Avance 400 narrow bore using a $5.0-\mathrm{mm}$ probe. The spectrometer settings were 2s relaxation delay; 1024 scans for the polar fraction and 128 scans for the apolar fraction, with four dummy scans in all cases; a spectral width of $5000 \mathrm{~Hz}$; a 60 degree pulse; acquisition in $16 \mathrm{~K}$ data points. Prior to data analysis, the raw NMR data were subjected to a squared sine bell filter (shifted $1 / 2 \mathrm{pi}$ ), zero-filling to $128 \mathrm{~K}$ data points, Fourier transformation and phase correction.

NMR raw data and the corresponding metadata are provided as an additional file (see Additional file 2).

\section{GC-MS analysis}

Derivatisation A miniature scale BF3-mediated methanolysis method for derivatizing fatty acids (for GC-MS) was used. In brief: $132 \mu \mathrm{l}$ of the apolar fraction was dried under nitrogen. To this dry extract, $40 \mu \mathrm{l}$ of $0.5 \mathrm{~N}$ $\mathrm{NaOH}$ in $\mathrm{MeOH}$ was added. The capped vial was placed in a pre-heated oven at $65^{\circ} \mathrm{C}$ for 30 minutes after which $50 \mu \mathrm{l}$ of BF3 (20\% in methanol) was added. After closing it again, the vial was put in the oven for three minutes at $65^{\circ} \mathrm{C} ; 0.2 \mathrm{ml}$ of iso-octane was added. The vial was again closed and put in the oven for two minutes at $65^{\circ}$ C. After cooling, the volume was adjusted to $1 \mathrm{ml}$ with a saturated $\mathrm{NaCl}$ solution. This was shaken firmly and the content was left to separate into two phases. The vial was centrifuged at $2800 \mathrm{rpm}$ and the upper phase was carefully collected. For GC-MS analysis, $75 \mu \mathrm{l}$ of the iso-octane phase was transferred into a new vial and kept at $-20^{\circ} \mathrm{C}$ pending analysis.

GC-MS A Trace GC 2000 series gas chromatograph interfaced with a Trace MS Plus mass spectrometer (Thermo Finnigan, San Jose, CA) was used for GC/MS analysis. Two $\mu \mathrm{l}$ of sample was injected using a PTVSplitless injection. For the separations, a RTX-5 column (length $10 \mathrm{~m}$, internal diameter $0.18 \mathrm{~mm}$, stationary phase film 0.20_m; Alltech, Breda, The Netherlands) was used with helium as the carrier at a constant flow of $1.3 \mathrm{ml} / \mathrm{min}$. The $\mathrm{GC}$ temperature program was: 2 $\min$ at $80^{\circ} \mathrm{C}$; increase temperature at $5.5^{\circ} \mathrm{C} \min ^{-1}$ to $185^{\circ}$ $\mathrm{C}$ followed by $3.5^{\circ} \mathrm{C} \mathrm{min}^{-1}$ to $290^{\circ} \mathrm{C}$. This latter temperature was kept for $12 \mathrm{~min}$ and afterwards it decreased by $120^{\circ} \mathrm{C} \mathrm{m^{-1 }}$ to $150^{\circ} \mathrm{C}$. The GC-MS interface temperature was $280^{\circ} \mathrm{C}$; the source temperature was $200^{\circ} \mathrm{C}$. Mass scanning in EI (electron impact) mode was carried out for the range of $50-500 \mathrm{~m} / \mathrm{z}$ at a scan time of 0.4 seconds. The detector voltage was set to $500 \mathrm{~V}$ and the setting of the EI ionization source was $70 \mathrm{eV}$. All data were collected consecutively in one analysis series to minimize chromatography differences and the injection sequence was randomized according to Vos and coauthors [2].

Metadata for GS-MS files are provided as an additional file (see Additional file 2). Raw GS-MS data will be provided by a download link on request

\section{UPLC-TOF/MS analysis}

The fraction containing the polar metabolites was stored for a maximum of 4 months at $-20^{\circ} \mathrm{C}(\mathrm{pH}=5)$ before analysis by UPLC-TOF/MS. UPLC-TOF/MS samples were diluted twice with $\mathrm{D}_{2} \mathrm{O}$ prior to analysis; formic acid was added to a final concentration of $0.1 \%$. The injection sequence was randomized according to Vos and co-authors [2]. The analyses were performed on a LCT Premier LC-TOF-MS system (Waters, Milford, MA, USA) equipped with a dual spray electrospray source. The lock mass calibrant (leucine/enkephaline) was measured every 10 scans. The gradient was provided by an UPLC system (model Acquity, Waters) with a $150 \mathrm{~mm} \times 2.1 \mathrm{~mm}$ UPLC BEH-C8 column with 1.7 $\mu \mathrm{m}$ particles (Waters).

The mobile phase consisted of water, acetonitrile and formic acid (A:100/0/0.2 and B: 0/100/0.2). Gradient elution was performed at $0.4 \mathrm{ml} \mathrm{min} \mathrm{m}^{-1}$. The initial eluent composition, $100 \% \mathrm{~A}$, was held for one min after which the composition was changed to $85 \% \mathrm{~A}$ and $15 \% \mathrm{~B}$ in $14 \mathrm{~min}$. Afterwards, the composition of $\mathrm{B}$ was increased to $30 \%$ in $10 \mathrm{~min}$ and subsequently increased again to $90 \%$ in three min; this composition was maintained for five min. The injection volume was $10 \mu \mathrm{l}$. The effluent of the LC system was interfaced directly with the TOF-MS, which was operated in positive mode polarity. A stable spray was obtained with a capillary voltage of $2.5 \mathrm{kV}$, a source temperature of $120^{\circ} \mathrm{C}$ and desolvatation temperature of $350^{\circ} \mathrm{C}$. The desolvatation and cone gas flows were 600 and $50 \mathrm{~L} \mathrm{~h}^{-}$ 1 , respectively. The cone voltage was $50 \mathrm{~V}$. Spectra were collected in centroid mode from m/z 80 to 1500 , with a scan duration of $0.2 \mathrm{~s}$. Accurate masses were obtained after lock mass correction. The mass spectrometer was operated in W mode with the Dynamic Range Enhancement turned on and the resolution was 8500 (FWHM). 
Metadata for LC-MS files are provided as an additional file (see Additional file 2). Raw LC-MS data will be provided by a download link on request."

\section{LC-nanomate-Orbitrap analysis}

Liquid Chromatography-Mass Spectrometry (LCPDA-MS) The system consisted of an Accela U HPLC system (pump and auto sampler) equipped with an Accela PDA with a one cm light Pipe flow cell (ThermoFisher Scientific) and coupled to a LTQ/Orbitrap hybrid mass spectrometer (Thermo Fisher Scientific) that was equipped with a chip-based nano-electrospray ionization source (Triversa NanoMate (Advion BioSciences). The sample $(10 \mu \mathrm{l})$ was separated on a 150 $\mathrm{mm} \times 2.1 \mathrm{~mm}$ UPLC BEH-C8 column with $1.7 \mu \mathrm{m}$ particles (Waters). The flow rate was set at $0.4 \mathrm{ml} \mathrm{min}^{-1}$. Isopropanol (60 $\mu \mathrm{l} \mathrm{min}^{-1}$ of $\left.100 \%\right)$ was added between PDA and NanoMate via a T-junction to the LC flow to ensure a stable nanospray. The sample was loaded with $100 \%$ eluent $\mathrm{A}\left(\mathrm{H}_{2} \mathrm{O} / 0.1 \%\right.$ formic acid). The gradient was the same as that used for the UPLC-TOF/MS analysis. The PDA detector, placed between the analytical column and the NanoMate, was programmed to acquire data every second from 210 to $600 \mathrm{~nm}$ with a resolution of $1 \mathrm{~nm}$ and $2 \mathrm{~Hz}$ sampling rate. The NanoMate source was operated in the positive ionization mode with a HD_A_384 chip with a spray voltage of $1.4 \mathrm{kV}$ and 0.4 psi $\mathrm{N}_{2}$ gas. The NanoMate was used in the LC coupling mode with fraction collection. The total flow $(460 \mu \mathrm{l} /$ min) was split using capillary tubing for MS spray (480 $\mathrm{nl} / \mathrm{min})$ and for fractionation $(459.5 \mu \mathrm{l} / \mathrm{min})$. Fractions were collected by the NanoMate from retention time 0.5 to $19.5 \mathrm{~min}$ in $3 \mathrm{~s}$ fractions $(23 \mu \mathrm{l})$ in a 384 well plate (twin tec, Eppendorf). The plate temperature was set at $10^{\circ} \mathrm{C}$. After collection, extra isopropanol $(5 \mu \mathrm{l})$ was added. The plate was sealed to prevent evaporation of the fractions. These fractions were used in the $M S^{n}$ experiments. Parallel to the fractionation, the MS spray from the NanoMate was used to record a full FTMS scan (m/z 80-1000) with resolution of 15.000 (at $\mathrm{m} / \mathrm{z}$ 400). Automatic tuning was carried out on $\mathrm{m} / \mathrm{z} 566.89$. The full AGC target was set to 30000 . The Orbitrap was externally calibrated in positive mode using sodium formate clusters in the range $\mathrm{m} / \mathrm{z}$ 158.69-1110.79.

$M^{\boldsymbol{n}}$ by direct infusion The system consisted of a LTQ/ Orbitrap hybrid mass spectrometer (Thermo Fisher Scientific) equipped with a chip-based nano-electrospray ionization source (Triversa NanoMate, Advion BioSciences). After manually selecting the masses of interest, recorded in the full scan MS, the fractions containing these masses were subjected to $\mathrm{MS}^{\mathrm{n}}$ fragmentation in positive mode. Delivery of the sample to MS: The NanoMate used a pipette tip to take the sample from a selected well and infused this sample to the MS via the spray nozzle on the chip. NanoMate parameters were: spray voltage $1.7 \mathrm{kV}$ and $0.6 \mathrm{psi} \mathrm{N}_{2}$ gas. The mass spectrometer was tuned on $\mathrm{m} / \mathrm{z}$ 566.89. The full AGC target was set to 30000 . The Orbitrap was externally calibrated in positive mode using sodium formate clusters in the range $\mathrm{m} / \mathrm{z} 158.69-1110.79$. For performing the $\mathrm{MS}^{\mathrm{n}}$ experiments in MS1 a window of $1 \mathrm{~m} / \mathrm{z}$ was used to isolate the mass of interest. The resolution used in the MS1 scan event was 60.000. For all dependent scan events (MSn) a resolution of 15000 and normalized collision energy $35 \%$ was used.

$\mathrm{MS}^{\mathrm{n}}$ description:

MS 1 Full scan with limited $\mathrm{m} / \mathrm{z}$ range, $\mathrm{m} / \mathrm{z}$ of interest $\pm 0.5 \mathrm{~m} / \mathrm{z}$

MS 2 fragmentation of most intense $\mathrm{m} / \mathrm{z}$ of MS1

MS 3 fragmentation of five most intense fragments in MS2

MS 4 fragmentation of five most intense fragments in MS3

MS 5 fragmentation of three most intense fragments in MS4

Following the sample infusion and MS analysis, the pipette tip was ejected and a new tip and nozzle were used for each sample, thereby preventing any cross-contamination or carry-over.

\section{Data analysis}

\section{NMR data analysis}

Pre-processing of the data and alignment A visual inspection of the technical replicates (4-fold) of each sample was carried out to ensure a high degree of reproducibility. The NMR data were pre-processed and aligned using a program developed in-house. This program was described in the Materials and Methods section of the paper by Lommen et al. [32], but has been adapted to run under Windows.

Normalization The aligned fingerprint data in the form of generated spreadsheets were normalized using factors obtained from the scaling on the phospholipid signals of the ${ }^{1} \mathrm{H}$ NMR spectra of the apolar fraction (see RESULTS section).

Statistical analysis The normalized spreadsheets of both datasets were subjected to statistical analysis using Genemaths XT [79]. Standard initial analysis entailed performing a ${ }^{2}$ Log transformation and a PCA (average of rows and columns subtracted). This was followed by a ${ }^{2}$ Log transformation, a pre-selection of variables using an ANOVA $(\mathrm{p}<0.01)$ followed by a PCA (average of rows and columns subtracted). An example of the effect of the ANOVA is given in Figure S2 in the Additional File 1 . The grouping in the ANOVA was on the replicates per treatment for each passage number of cells when the effect of passage number as well as treatment 
was studied (10 groups with 5 replicates). The grouping in the ANOVA was on all replicates per treatment irrespective of passage number when only the effect of treatment was studied (2 groups of each 25 samples). From the latter figure a selection of peak loadings underlying the separation by treatment in the PCA could be exported as described in [31] (an example is given in Additional File 1, Figure S3); to check that the numbers of variables selected exceeded that expected purely by chance, table S1 was added in the Additional File 1 . Only differences with a fold change higher than 1.2 and surviving a Bonferroni false positive correction were taken into account.

Identification of metabolites The identification of relevant signals from the NMR data was carried out by using commercially available standards and/or from literature and databases, such as HMDB [80].

\section{MS data analysis}

Pre-processing of the data and alignment A visual inspection of the technical replicates (4-fold) of each sample was carried out to ensure that high degree of reproducibility. The GC-MS and LC-MS data were preprocessed and aligned using MetAlign [31,34]. In short, this software performs a baseline correction, accurate mass calculation, data smoothing and noise reduction, followed by alignment between chromatograms, generating data files that are reduced in size 100-1000 times. The pre-processing and alignment parameters used have been included as Figures S4 and S5 in Additional File 1.

\section{Normalization}

\section{LC-MS data}

The aligned fingerprint data of the polar fraction dataset, in the form of generated spreadsheets, were normalized using the phospholipid scaling factors obtained from the ${ }^{1} \mathrm{H}$ NMR spectra of the apolar fraction (see RESULTS section).

\section{GC-MS data}

The identified peaks of GC-MS chromatograms were manually integrated. This fraction was normalized by scaling to the raw values of the integrals of docosahexaenoic and arachidonic methyl esters (see RESULTS section).

Statistical analysis The same procedure as described in the NMR section was used.

Identification of metabolites A method of facilitating further analysis and identification was accomplished using GM2MS, an application of MetAlign that re-creates "new chromatograms" that contain only the peaks exported from the PCA selection [31]. Polar metabolites were identified with commercially available standards, with FT-MS/MS analysis and using databases, such as the HMDB [80]. Fatty acids were identified using the eluting order of the peaks and the NIST mass spectral library.

\section{Additional material}

Additional file 1: PDF file containing Figures S1, S2, S3, S4 and S5 and Tables S1, S2, S3, S4, S5 and S6, mentioned in the text.

Additional file 2: Metadata and NMR raw data: ZIP file containing -All NMR raw data (in JCAMP-DX format ".dx") -The metadata on NMR (polars \& apolars), LC-MS and GC-MS data sets (as Tab delimited files ". txt").

\section{Acknowledgements}

The Netherlands Toxicogenomics Centre, NTC (http://www.toxicogenomics. $\mathrm{nl}$ ) is acknowledged for funding this project through a postdoctoral grant. The Basque Government is thanked for funding a postdoctoral grant through the "Programa de Formación de Investigadores del Departamento de Educación, Universidades e Investigación". Jenneke Poortman (RIKILT), Bert Schipper (PRI), Arjen Gerssen (RIKILT) and Gerrit Bor (RIKILT) are thanked for their assistance in respect of the cell exposure, LC-nanomate-MS, LC-MS and GC-MS experiments.

\section{Author details}

${ }^{1}$ RIKILT-Institute of Food Safety, Wageningen University and Research Centre, P.O. Box 230, 6700 AE, Wageningen, The Netherlands. ${ }^{2}$ Department of Health Risk Analysis and Toxicology, P.O. Box 616, 6200 MD Maastricht University, Maastricht, The Netherlands. ${ }^{3}$ Netherlands Toxicogenomics Centre, The Netherlands.

\section{Authors' contributions}

$A P, J K, J$ van D and DJ participated in the design of the study and overall discussion; $\mathrm{CH}$ helped to set up the methodology for in vitro metabolomics experiments; ARA optimized protocols, performed cell culture, exposures and collection of data; ARA and AL analysed data and interpreted the results. All authors read and approved the final manuscript. None of the authors had any personal or financial conflict of interest.

Received: 25 June 2010 Accepted: 20 May 2011 Published: 20 May 2011

\section{References}

1. Nicholson JK, Lindon JC, Holmes E: Metabonomics: understanding the metabolic responses of living systems to pathophysiological stimuli via multivariate statistical analysis of biological NMR spectroscopic data. Xenobiotica 1999, 29:1181-1189.

2. De Vos RCH, Moco S, Lommen A, Keurentjes JJB, Bino RJ, Hall RD: Untargeted large-scale plant metabolomics using liquid chromatography coupled to mass spectrometry. Nat Protoc 2007, 2:778-791.

3. Lommen A, van der Weg G, van Engelen MC, Bor G, Hoogenboom LAP, Nielen MWF: An untargeted metabolomics approach to contaminant analysis: Pinpointing potential unknown compounds. Anal Chim Acta 2007, 584:43-49.

4. Fernie AR, Schauer N: Metabolomics-assisted breeding: a viable option for crop improvement? Trends Genet 2008, 25:39-48.

5. Griffin $J$ : Understanding mouse models of disease through metabolomics. Curr Opin Chem Biol 2006, 10:309-315.

6. Kaddurah-Daouk R, Kristal BS, Weinshilboum RM: Metabolomics: A Global Biochemical Approach to Drug Response and Disease. Annu Rev Pharmacol Toxicol 2008, 48:653-683.

7. Powers R: NMR metabolomics and drug discovery. Magn Reson Chem 2009, 47:S2-S11.

8. Coen M, Holmes E, Lindon JC, Nicholson JK: NMR-Based Metabolic Profiling and Metabonomic Approaches to Problems in Molecular Toxicology. Chem Res Toxicol 2008, 21:9-27.

9. Beger RD, Sun J, Schnackenberg LK: Metabolomics approaches for discovering biomarkers of drug-induced hepatotoxicity and nephrotoxicity. Toxicol Appl Pharmacol 243:154-166.

10. Ellis JK, Chan PH, Doktorova T, Athersuch TJ, Cavill R, Vanhaecke T, Rogiers V, Vinken M, Nicholson JK, Ebbels T MD, Keun HC: Effect of the Histone Deacetylase Inhibitor Trichostatin A on the Metabolome of Cultured Primary Hepatocytes. J Proteome Res 2009, 9:413-419. 
11. van Vliet E, Morath S, Eskes C, Linge J, Rappsilber J, Honegger P, Hartung T, Coecke S: A novel in vitro metabolomics approach for neurotoxicity testing, proof of principle for methyl mercury chloride and caffeine. Neurotoxicology 2008, 29:1-12.

12. Vanhaecke T, Snykers S, Rogiers V, Garthoff B, Castell J, Hengstler J: EU research activities in alternative testing strategies: current status and future perspectives. Arch Toxicol 2009, 83:1037-1042.

13. Corvi R: Genomics: an in vitro toxicology point of view. Altern Lab Anim 2002, 30:129-131.

14. Snodin DJ: An EU perspective on the use of in vitro methods in regulatory pharmaceutical toxicology. Toxicol Lett 2002, 127:161-168.

15. Jennen DGJ, Magkoufopoulou C, Ketelslegers HB, van Herwijnen MHM, Kleinjans JCS, van Delft JHM: Comparison of HepG2 and HepaRG by Whole-Genome Gene Expression Analysis for the Purpose of Chemical Hazard Identification. Toxicol Sci 2010, 115:66-79.

16. van Delft JHM, van Agen E, van Breda SGJ, Herwijnen MH, Staal YCM, Kleinjans JCS: Discrimination of genotoxic from non-genotoxic carcinogens by gene expression profiling. Carcinogenesis 2004, 25:1265-1276.

17. van Delft JHM, van Agen E, van Breda SGJ, Herwijnen MH, Staal YCM, Kleinjans JCS: Comparison of supervised clustering methods to discriminate genotoxic from non-genotoxic carcinogens by gene expression profiling. Mutat Res, Fundam Mol Mech Mutagen 2005, 575:17-33.

18. Winkler J, Sotiriadou I, Chen S, Hescheler J, Sachinidis A: The Potential of Embryonic Stem Cells Combined with -omics Technologies as Model Systems for Toxicology. Curr Med Chem 2009, 16:4814-4827.

19. Landers JP, Bunce NJ: The Ah receptor and the mechanism of dioxin toxicity. Biochem J 1991, 276:273-287.

20. Mandal PK: Dioxin: a review of its environmental effects and its aryl hydrocarbon receptor biology. J Comp Physiol, B 2005, 175:221-230.

21. Uno S, Dalton TP, Sinclair PR, Gorman N, Wang B, Smith AG, Miller ML, Shertzer HG, Nebert DW: Cyp1a1(-/-) male mice: protection against highdose TCDD-induced lethality and wasting syndrome, and resistance to intrahepatocyte lipid accumulation and uroporphyria. Toxicol Appl Pharmacol 2004, 196:410-421.

22. Senft AP, Dalton TP, Nebert DW, Genter MB, Hutchinson RJ, Shertzer HG: Dioxin Increases Reactive Oxygen Production in Mouse Liver Mitochondria. Toxicol Appl Pharmacol 2002, 178:15-21.

23. Shertzer HG, Nebert DW, Puga A, Ary M, Sonntag D, Dixon K, Robinson LJ, Cianciolo E, Dalton TP: Dioxin Causes a Sustained Oxidative Stress Response in the Mouse. Biochem Biophys Res Commun 1998, 253:44-48.

24. Poland A, Knutson JC: 2,3,7,8-Tetrachlorodibenzo-p-Dioxin and Related Halogenated Aromatic Hydrocarbons: Examination of the Mechanism of Toxicity. Annu Rev Pharmacol Toxicol 1982, 22:517-554.

25. Safe S: Molecular biology of the Ah receptor and its role in carcinogenesis. Toxicol Lett 2001, 120:1-7.

26. Puga A, Maier A, Medvedovic M: The transcriptional signature of dioxin in human hepatoma HepG2 cells. Biochem Pharmacol 2000, 60:1129-1142.

27. Hankinson O: The Aryl Hydrocarbon Receptor Complex. Annu Rev Pharmacol Toxicol 1995, 35:307-340.

28. Knasmüller S, Parzefall W, Sanyal R, Ecker S, Schwab C, Uhl M, MerschSundermann V, Williamson G, Hietsch G, Langer T, Darroudi F, Natajaran AT: Use of metabolically competent human hepatoma cells for the detection of mutagens and antimutagens. Mutat Res, Fundam Mol Mech Mutagen 1998, 402:185-202.

29. Hockley SL, Mathijs K, Staal YCM, Brewer D, Giddings I, van Delft JHM, Phillips DH: Interlaboratory and Interplatform Comparison of Microarray Gene Expression Analysis of HepG2 Cells Exposed to Benzo(a)pyrene. OMICS 2009, 13:115-125.

30. Wilkening S, Stahl F, Bader A: Comparison of primary human hepatocytes and hepatoma cell line HepG2 with regard with their biotransformation properties. Drug Metab Dispos 2003, 31:1035-1042.

31. Lommen A: MetAlign: Interface-Driven, Versatile Metabolomics Tool for Hyphenated Full-Scan Mass Spectrometry Data Preprocessing. Anal Chem 2009, 81:3079-3086.

32. Lommen A, Weseman JM, Smith GO, Noteborn HPJM: On the detection of environmental effects on complex matrices combining off-line liquid chromatography and 1H-NMR. Biodegradation 1998, 9:513-525.
33. Noteborn HPJM, Lommen A, van der Jagt RC, Weseman JM: Chemical fingerprinting for the evaluation of unintended secondary metabolic changes in transgenic food crops. J Biotechnol 2000, 77:103-114.

34. MetAlign. [http://www.metalign.nl].

35. Kinehara M, Fukuda I, Yoshida Ki, Ashida H: Aryl hydrocarbon receptormediated induction of the cytosolic phospholipase $A(2)$ alpha gene by 2,3,7,8-tetrachlorodibenzo-p-dioxin in mouse hepatoma Hepa-1c1c7 cells. J Biosci Bioeng 2009, 108:277-281.

36. Dayoub R, Thasler WE, Bosserhoff AK, Singer T, Jauch KW, Schlitt HJ, Weiss TS: Regulation of polyamine synthesis in human hepatocytes by hepatotrophic factor augmenter of liver regeneration. Biochem Biophys Res Commun 2006, 345:181-187.

37. Raasch W, Regunathan S, Li G, Reis DJ: Agmatine, the bacterial amine, is widely distributed in mammalian tissues. Life Sci 1995, 56:2319-2330.

38. Potter $\mathrm{CL}$, Sipes IG, Russell $\mathrm{DH}$ : Inhibition of ornithine decarboxylase activity by 2,3,7,8-tetrachlorodibenzo-p-dioxin. Biochem Pharmacol 1982, 3:3367-3371

39. Thomas T, Mackenzie SA, Gallo MA: Regulation of polyamine biosynthesis by 2,3,7,8-tetrachlorodibenzo-p-dioxin (TCDD). Toxicol Lett 1990, 53:315-325.

40. Pegg AE, McCann PP: Polyamine metabolism and function. Am J Physiol. Cell Physiol 1982, 243:C212-221.

41. Boverhof DR, Burgoon LD, Tashiro C, Sharratt B, Chittim B, Harkema JR, Mendrick DL, Zacharewski TR: Comparative Toxicogenomic Analysis of the Hepatotoxic Effects of TCDD in Sprague Dawley Rats and C57BL/6 Mice. Toxicol Sci 2006, 94:398-416.

42. Fletcher $N$, Wahlström D, Lundberg R, Nilsson CB, Nilsson KC, Stockling K, Hellmold H, Håkansson H: 2,3,7,8-Tetrachlorodibenzo-p-dioxin (TCDD) alters the mRNA expression of critical genes associated with cholesterol metabolism, bile acid biosynthesis, and bile transport in rat liver: $\mathrm{A}$ microarray study. Toxicol Appl Pharmacol 2005, 207:1-24.

43. Seefeld MD, Corbett SW, Keesey RE, Peterson RE: Characterization of the wasting syndrome in rats treated with 2,3,7,8-tetrachlorodibenzo-pdioxin. Toxicol Appl Pharmacol 1984, 73:311-322

44. Lakshman MR, Campbell BS, Chirtel SJ, Ekarohita N: Effects of 2,3,7,8tetrachlorodibenzo-p-dioxin (TCDD) on de novo fatty acid and cholesterol synthesis in the rat. Lipids 1988, 23:904-906.

45. Lakshman MR, Chirtel SJ, Chambers LL, Coutlakis PJ: Effects of 2,3,7,8tetrachlorodibenzo-p-dioxin on lipid synthesis and lipogenic enzymes in the rat. J Pharmacol Exp Ther 1989, 248:62-66.

46. McKim J, Marien K, Schaup H, Selivonchick D: Alterations of hepatic acetylCoA carboxylase by 2,3,7,8-tetrachlorodibenzo- $\mathrm{p}$-dioxin. Lipids 1991, 26:521-525.

47. Boverhof DR, Burgoon LD, Tashiro C, Chittim B, Harkema JR, Jump DB, Zacharewski TR: Temporal and Dose-Dependent Hepatic Gene Expression Patterns in Mice Provide New Insights into TCDD-Mediated Hepatotoxicity. Toxicol Sci 2005, 85:1048-1063.

48. Nishiumi S, Yabushita Y, Furuyashiki T, Fukuda I, Ashida H: Involvement of SREBPs in 2,3,7,8-tetrachlorodibenzo-p-dioxin-induced disruption of lipid metabolism in male guinea pig. Toxicol Appl Pharmacol 2008, 229:281-289.

49. Sato S, Shirakawa H, Tomita S, Ohsaki Y, Haketa K, Tooi O, Santo N, Tohkin M, Furukawa Y, Gonzalez FJ, Komai M: Low-dose dioxins alter gene expression related to cholesterol biosynthesis, lipogenesis, and glucose metabolism through the aryl hydrocarbon receptor-mediated pathway in mouse liver. Toxicol Appl Pharmacol 2008, 229:10-19.

50. Alexander DL, Ganem LG, Fernandez-Salquero P, Gonzalez F, Jefcoate CR: Aryl-hydrocarbon receptor is an inhibitory regulator of lipid synthesis and of commitment to adipogenesis. J Cell Sci 1998, 111:3311-3322.

51. Vogel CFA, Matsumura F: Interaction of 2,3,7,8-tetrachlorodibenzo-pdioxin (TCDD) with induced adipocyte differentiation in mouse embryonic fibroblasts (MEFs) involves tyrosine kinase c-Src. Biochem Pharmacol 2003, 66:1231-1244.

52. Ntambi JM, Miyazaki M, Stoehr JP, Lan H, Kendziorski CM, Yandell BS, Song Y, Cohen P, Friedman JM, Attie AD: Loss of stearoyl-CoA desaturase1 function protects mice against adiposity. Proc Natl Acad Sci USA 2002, 99:11482-11486.

53. Sewell AC, Böhles HJ: Acylcarnitines in intermediary metabolism. Eur J Pediatr 1995, 154:871-877.

54. Siliprandi N, Lisa F, Menabò R: Propionyl-L-carnitine: Biochemical significance and possible role in cardiac metabolism. Cardiovasc Drugs Ther 1991, 5:11-15 
55. Schiller CM, Adcock CM, Moore RA, Walden R: Effect of 2,3,7,8tetrachlorodibenzo-p-dioxin (TCDD) and fasting on body weight and lipid parameters in rats. Toxicol Appl Pharmacol 1985, 81:356-361.

56. Swift LL, Gasiewicz TA, Dunn GD, Soulé PD, Neal RA: Characterization of the hyperlipidemia in guinea pigs induced by $2,3,7,8-$ tetrachlorodibenzo-p-dioxin. Toxicol Appl Pharmacol 1981, 59:489-499.

57. Viluksela M, Unkila M, Pohjanvirta R, Tuomisto JT, Stahl BU, Rozman KK, Tuomisto J: Effects of 2,3,7,8-tetrachlorodibenzo-p-dioxin (TCDD) on liver phosphoenolpyruvate carboxykinase (PEPCK) activity, glucose homeostasis and plasma amino acid concentrations in the most TCDDsusceptible and the most TCDD-resistant rat strains. Arch Toxicol 1999, 73:323-336

58. Albro PW, Corbett JT, Harris M, Lawson LD: Effects of 2,3,7,8tetrachlorodibenzo-p-dioxin on lipid profiles in tissue of the Fischer rat. Chem Biol Interact 1978, 23:315-330

59. Hassan MQ, Stohs SJ, Murray WJ: Comparative ability of TCDD to induce lipid peroxidation in rats, guinea pigs, and Syrian golden hamsters. Bull Environ Contam Toxicol 1983, 31:649-657.

60. Pohjanvirta R, Sankari S, Kulju T, Naukkarinen A, Ylinen M, Tuomisto J: Studies on the Role of Lipid Peroxidation in the Acute Toxicity of TCDD in Rats. Pharmacol Toxicol 1990, 66:399-408.

61. Hilscherova K, Blankenship AL, Nie M, Coady KK, Upham BL, Trosko JE, Giesy JP: Oxidative stress in liver and brain of the hatchling chicken (Gallus domesticus) following in ovo injection with TCDD. Comp Biochem Physiol C Toxicol Pharmacol 2003, 136:29-45.

62. Deneke SM, Fanburg BL: Regulation of cellular glutathione. Am J Physiol Lung Cell Mol Physiol 1989, 257:L163-173.

63. Reed DJ: Glutathione: Toxicological Implications. Annu Rev Pharmacol Toxicol 1990, 30:603-631.

64. Aly HAA, Domènech O : Cytotoxicity and mitochondrial dysfunction of 2,3,7,8-tetrachlorodibenzo-p-dioxin (TCDD) in isolated rat hepatocytes. Toxicol Lett 2009, 191:79-87.

65. Kern PA, Fishman RB, Song W, Brown AD, Fonseca V: The effect of 2,3,7,8tetrachlorodibenzo-p-dioxin (TCDD) on oxidative enzymes in adipocytes and liver. Toxicology 2002, 171:117-125.

66. Hassan MQ, Stohs SJ, Murray WJ: Inhibition of TCDD-induced lipid peroxidation, glutathione peroxidase activity and toxicity by BHA and glutathione. Bull Environ Contam Toxicol 1985, 34:787-796.

67. Schmidt A, Marescau B, Boehm EA, Renema WKJ, Peco R, Das A, Steinfeld R, Chan S, Wallis J, Davidoff M, Ullrich K, Waldschütz R, Heerschap A, De Deyn PP, Neubauer S, Isbrandt D: Severely altered guanidino compound levels, disturbed body weight homeostasis and impaired fertility in a mouse model of guanidinoacetate $\mathrm{N}$-methyltransferase (GAMT) deficiency. Hum Mol Gen 2004, 13:905-921.

68. Huxtable RJ: Physiological actions of taurine. Physiol Rev 1992, 72:101-163.

69. Park T, Oh J, Lee K: Dietary taurine or glycine supplementation reduces plasma and liver cholesterol and triglyceride concentrations in rats fed a cholesterol-free diet. Nutr Res 1999, 19:1777-1789.

70. Yanagita T, Han SY, Hu Y, Nagao K, Kitajima H, Murakami S: Taurine reduces the secretion of apolipoprotein B100 and lipids in HepG2 cells. Lipids Health Dis 2008, 7:38.

71. Cimafranca MA, Hanlon PR, Jefcoate CR: TCDD administration after the pro-adipogenic differentiation stimulus inhibits PPARY through a MEKdependent process but less effectively suppresses adipogenesis. Toxicol Appl Pharmacol 2004, 196:156-168.

72. Hanlon PR, Zheng W, Ko AY, Jefcoate CR: Identification of novel TCDDregulated genes by microarray analysis. Toxicol Appl Pharmacol 2005, 202:215-228.

73. Konrad RJ, Kudlow JE: The role of O-linked protein glycosylation in betacell dysfunction. Int J Mol Med 2002, 10:535-539.

74. Wagner KW, Punnoose EA, Januario T, Lawrence DA, Pitti RM, Lancaster $K$, Lee D, von Goetz M, Yee SF, Totpal K, Huw L, Katta V, Cavet G, Hymowitz SG, Amler L, Ashkenazi A: Death-receptor O-glycosylation controls tumor-cell sensitivity to the proapoptotic ligand Apo2L/TRAIL. Nat Med 2007, 13:1070-1077.

75. Kim S, Dere E, Burgoon LD, Chang CC, Zacharewski TR: Comparative Analysis of AhR-Mediated TCDD-Elicited Gene Expression in Human Liver Adult Stem Cells. Toxicol Sci 2009, 112:229-244.

76. Kim JH, In YJ, Kim WK, Bae KH, Kang S, Lee SC: Differential signatures of protein glycosylation and phosphorylation in human Chang liver cells induced by TCDD treatment. Toxicol Lett 2008, 178:20-28.
77. Baslow MH: N-Acetylaspartate in the Vertebrate Brain: Metabolism and Function. Neurochem Res 2003, 28:1573-6903.

78. Rubin Y, Connelly GP, Lenkinski RE: N-acetylaspartate complexes with calcium and lanthanide ions. J Inorg Biochem 1995, 60:31-43.

79. GeneMaths. [http://www.applied-maths.com/genemaths/genemaths.htm]

80. The Human Metabolome Database. [http://www.hmdb.ca/].

81. Oostendorp M, Engelke UFH, Willemsen MAAP, Wevers RA: Diagnosing Inborn Errors of Lipid Metabolism with Proton Nuclear Magnetic Resonance Spectroscopy. Clin Chem 2006, 52:1395-1405.

82. Fan TWM, Lane AN: Structure-based profiling of metabolites and isotopomers by NMR. Prog Nucl Magn Reson Spectrosc 2008, 52:69-117.

83. Govindaraju V, Young K, Maudsley AA: Proton NMR chemical shifts and coupling constants for brain metabolites. NMR Biomed 2000, 13:129-153.

doi:10.1186/1471-2164-12-251

Cite this article as: Ruiz-Aracama et al: An untargeted multi-technique metabolomics approach to studying intracellular metabolites of HepG2 cells exposed to 2,3,7,8-tetrachlorodibenzo-p-dioxin. BMC Genomics 2011 12:251.

\section{Submit your next manuscript to BioMed Central and take full advantage of:}

- Convenient online submission

- Thorough peer review

- No space constraints or color figure charges

- Immediate publication on acceptance

- Inclusion in PubMed, CAS, Scopus and Google Scholar

- Research which is freely available for redistribution 